PNL-2518

UC-60

\title{
Preliminary Results of a Field Experiment to Characterize Wind Flow Through a Vertical Plane
}

by

M. Gary Verholek

April 1978

Pacific Northwest Laboratory

Richland, Washington 99352

Operated for the

U.S. Department of Energy

by 


\title{
NOTICE
}

This report was prepared as an account of work sponsored by the United States Government. Neither the United States nor the Department of Energy, nor any of their employees, nor any of their contractors, subcontractors, or their employees, makes any warranty, express or implied, or assumes any legal liability or responsibility for the accuracy, completeness or usefulness of any information, apparatus, product or process disciosed, or represents that its use would not infringe privately owned rights.

The views, opinions and conclusions contained in this report are those of the contractor and do not necessarily represent those of the United States Government or the United States Department of Energy.

\author{
PACIFIC NORTHWIEST LABORATORY \\ operated by \\ BATTELLE \\ for the \\ UNITED STATES DEP.ARTMENT OF ENERGY \\ Under Contract EY-76-C-06-1830
}

Printed in the United States of Ameri
Available from
National Technical Information Service
United States Department of Commerce
5285 Port Royal Road
Springfield, Virginia 22151
Price: Printed Copy

*Pages


PNL-2518

$\mathrm{UC}-60$

PRELIMINARY RESULTS OF A FIELD

EXPERIMENT TO CHARACTERIZE WIND

FLOW THROUGH A VERTICAL PLANE

by

M. Gary Verholek

April 1978

Prepared for the U. S. Department of Energy under Contract EY-76-C-06-1830.

PACIFIC NORTHWEST LABORATORY

Richland, Washington 99352

Operated by

BATTELLE MEMORIAL INSTITUTE 
This report contains preliminary results of a field experiment to study the turbulent structure in the wind flow through a simulated disc of rotation of a large, horizontal-axis wind turbine blade. The wind flow impinging on the hypothetical turbine blade was simulated by a nine-element circular array of three component anemometers in a single vertical plane. The wind data were analyzed as: a single point, hub height measurement (at the center of the array); an arithmetic average of all sensors; and a synthesis of the data records assumed to represent measurement locations on a hypothetical, rotating turbine blade. The effects of areal averaging were examined using the arithmetic mean over the array. Similarly, the effects of averaging over the blade pair were examined by arithmetically averaging opposing data points representing the air flow past the rotating blade.

Wind flow through hypothetical, rotating turbine blades was simulated by sampling the anemometer records in a sequence around the array as if a sensor were on a turbine blade rotating in the plane of the array. The synthesized wind records were used to simulate the flow into a soft, flexible blade loaded by the actual nonuniform wind field, and a stiff, nonflexible blade that averaged the flow over the entire rotor.

The differences in the analytical results obtained in this study illustrate some of the differences that can result from using various atmospheric flow field assumptions when designing wind turbines. This study does not attempt to determine the applicability of given assumptions; differences are pointed out to aid designers in deciding which assumptions are most appropriate. 



\section{CONTENTS}

SUMMARY. . . . . . . . . . . . . . . . ii

FIGURES. . . . . . . . . . . . . . . . iv

1.0 INTRODUCTION. . . . . . . . . . . . . . . 1

2.0 CONCLUSIONS . . . . . . . . . . . . . 3

3.0 EXPERIMENTAL PROCEDURES . . . . . . . . . . . 5

4.0 WIND DATA ANALYSIS. . . . . . . . . . . . . 9

4.1 ANALYSIS PROCEDURES. . . . . . . . . . . . 9

4.2 PRELIMINARY RESULTS AND COMPARISONS. . . . . 11

4.2.1 Sample Traces .......... 12

4.2.2 Spatial Correlations. . . . . . . 13

4.2.3 Frequency Distributions of Turbulence 13

Parameters. . . . . . . . . .

4.2.4 Power Spectral Estimates. . . . . . 15

5.0 REFERENCES. . . . . . . . . . . . . . 33 


\section{FIGURES}

1 Schematic of Instrument Array for Vertical Plane Field Experiment. . . . . . . . .

Trace of the Longitudinal Wind Component, Hub Versus Array Average. . . . . . . . .

Trace of the Longitudinal wind Component, Hub Versus Blade Average. . . . . . . .

Trace of the Longitudinal Component of the Synthesized Wind. . . . . . . . . .

Cumulative Frequency Distribution of the Change in velocity, $\Delta u$, in time $\Delta t$ for the HUB (Case 1). . . . . . . . . . . .

Cumulative Frequency Distribution of the Change in Velocity, $\Delta u$, in time $\Delta t$ for the ARRAY AVERAGE (Case 2). . . . . . . . .

Cumulative Frequency Distribution of the Change in velocity, $\Delta u$, in time $\Delta t$ for a Single BLADE (Case 3) . . . . . . . .

Cumulative Frequency Distribution of the Change in velocity, $\Delta u$, in time $\Delta t$ for the BLADE AVERAGE (Case 4). . . . . . . .

10 Cumulative Frequency Distribution of the Change in Direction, $\Delta \theta$, in time $\Delta t$ for the HUB (Case 1). . . . . . . . . .

11 Cumulative Frequency Distribution of the Change in Direction, $\Delta \theta$, in time $\Delta t$ for the ARRAY AVERAGE (Case 2). . . . . : . .

12 Cumulative Frequency Distribution of the Change in Direction, $\Delta \theta$, in time $\Delta t$ for a BLADE (Case 3). . . . . . . . . . . . 
13 Cumulative Frequency Distribution of the Change in Direction, $\Delta \theta$, in time $\Delta t$ for the BLADE AVERAGE (Case 4).........

Power Spectra of Hub and Array Average. .

Power Spectra of Hub and Blade Average. .

Power Spectra of Hub and Blade Tip. . . . 



\section{PRELIMINARY RESULTS OF A FIELD EXPERIMENT \\ TO CHARACTERIZE WIND FLOW THROUGH}

A VERTICAL PLANE

M. Gary Verholek

\subsection{INTRODUCTION}

In early 1977, Pacific Northwest Laboratory (PNL) initiated a Department of Energy-sponsored field experiment to study the turbulence structure of the flow field through the simulated disc of rotation of the blades of a hypothetical, large horizontal axis wind turbine. This experiment was conducted on DOE's Hanford Area in the desert of eastern Washington. The objective was to characterize the wind impinging on hypothetical wind turbine blades rotating in a vertical plane and to examine how it differed from that experienced by a single hub-height anemometer.

Three component wind measurements on a circular array of anemometers in a vertical plane were used to describe the flow. The wind data were analyzed as a single point, hub height measurement at the center of the array, as an arithmetic average of all sensors, and as a synthesis of the data records simulating measurement locations on the hypothetical, rotating turbine blade. The synthesized wind records were specifically analyzed from the aspect of a "soft" blade (single record) and a "stiff" blade (average of the data from opposing anemometers.) 


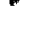




\subsection{CONCLUSIONS}

The differences in the analytical results obtained for the four cases established for this study illustrate the differences that can result from using various atmospheric flow field assumptions when designing wind turbines. This study does not question the applicability of any given assumption; rather, the differences are stressed so that designers can better decide which assumptions are appropriate.

These results are preliminary and the direction of the continuing research will depend to a great extent on the response of the turbine designers. While the project is meteorologically interesting in itself, it was intended to provide designers with insight into the structure of the flow through the disc of rotation of a turbine blade. In addition, data stored on nine-track tapes are available to other technical organizations for appropriate applications. Tapes of data segments may be obtained from PNL if it is determined that the data are appropriate for the intended application. 


\subsection{EXPERIMENTAL PROCEDURES}

For the field experiment, a circular array of anemometers $24.4 \mathrm{~m}$ (80 ft) in diameter was situated on five towers in a common plane (Fig. 1). The array was centered $24.4 \mathrm{~m}$ above the ground to simulate the disc of a large wind turbine blade $24.4 \mathrm{~m}$ in diameter. Eight R.M. Young, Model 27004, Gill uvw-anemometers were located on the five towers in a circular pattern at $45^{\circ}$ separation, and a ninth anemometer was located at the center of the array.

The three Gills on the center tower were equipped with thermistors for determining temperature data. The thermistors were calibrated in a controlled temperature bath against a highly accurate mercury thermometer.

The Gill anemometers were tested in a wind tunnel to check the bearings and generators and to calibrate each sensor. The generators were calibrated using an 1800-rpm, constant speed motor and these calibrations were used to adjust a translator unit which provides input to a mini-computer over a range of -1 to +1 volt.

Every 0.1 sec the entire array of sensors was sampled and the voltages recorded. These voltages were later converted to temperature and velocity (corrected for the noncosine response of the Gills) and placed on nine-track tapes. Data were recorded in 1500-data point blocks, corresponding to 50 scans of the 30 sensors ( 9 times, $u, v, w$, and 3 temperatures). The observations were ordered sequentially around the array. The sampling sequence begins at the "hub" or center of the circular array, moves to the top anemometer and then progresses at $45^{\circ}$ intervals around the circular array for nine values of $u$, $v, w$ and three temperatures sampled from bottom to top. 
GILL ANEMOMETERS NO. 1-9

TEMPERATURE PROBES NO. 10-12

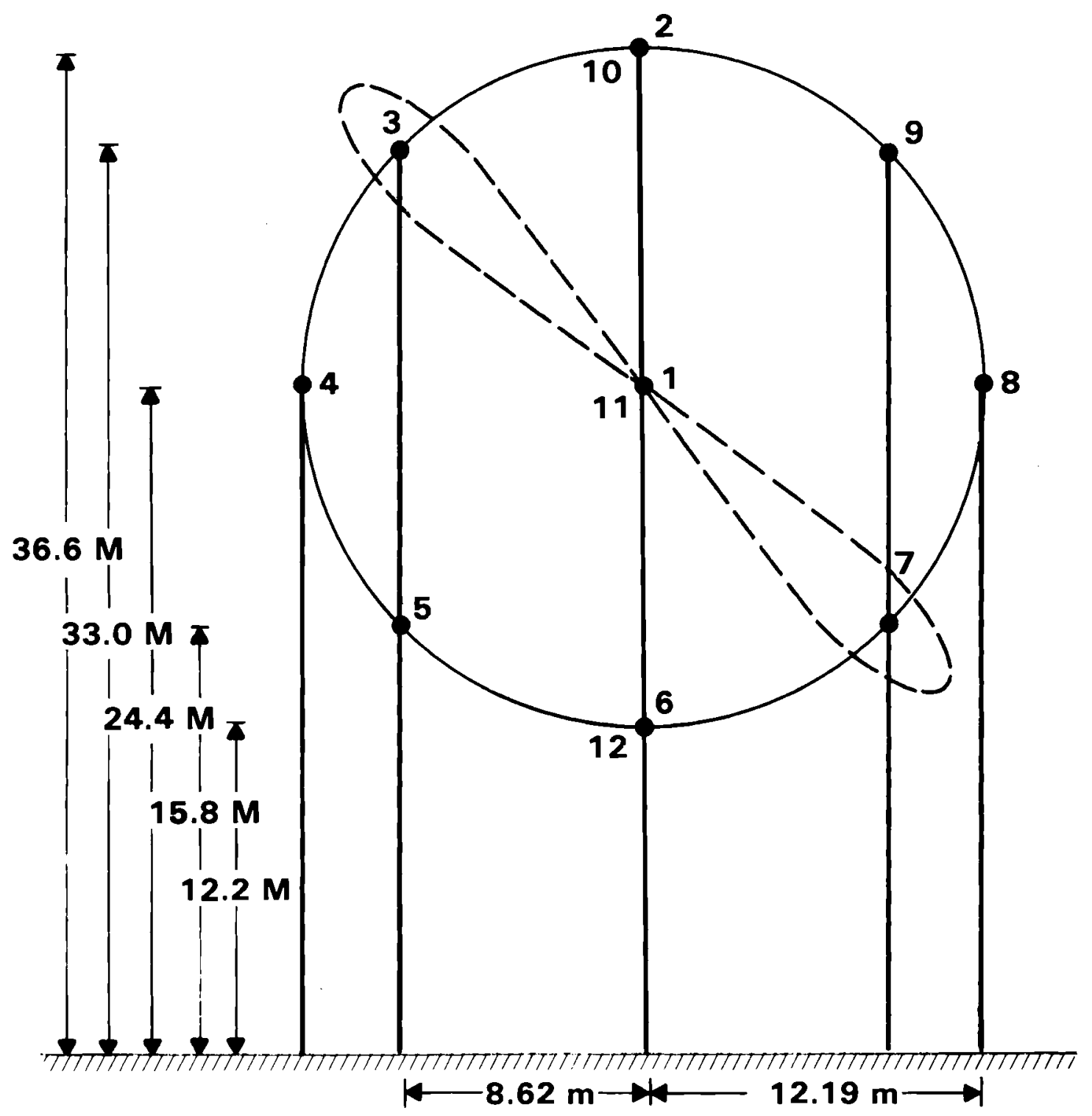

Figure 1. Schematic of Instrument Array for
Vertical Plane Field Experiment 
Several data collection runs resulted in slightly less than 8 and $\frac{1}{2}$ hours of data.

The data are stored on nine-track tape and are available to other technical organizations for appropriate applications. Tapes of data segments may be obtained from PNL following a determination that the data are acceptable for the intended application. 


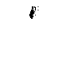




\subsection{WIND DATA ANALYSIS}

Wind data analyses were performed for the following cases:

Case 1. the single hub anemometer,

Case 2. the arithmetic average over the array,

Case 3. a synthesized wind record representing a measurement location on either rotating blade,

Case 4. an arithmetic average of two complementary, synthesized records (one for each blade of the rotor).

Case 1 represents the situation in which only one sensor is available to characterize the flow into a blade and it is assumed that data taken at the hub will adequately characterize the flow over the rotor disc. Case 2 examines the spatial average and its relation to the single hub anemometer. Case 3 represents the situation of a soft, flexible blade. The soft blade is stressed as a result of differential loading along the blade elements. Therefore, the scale and structure of the turbulence are very important and act on each blade element independently. Case 4 represents the situation of a stiff blade (i.e., a blade that does not flex but merely averages the flow at both spars). For both cases 3 and 4, results are compared to those for the single hub-height anemometer.

\subsection{ANALYSIS PROCEDURES}

Both the single "hub" anemometer data and averaged data from the entire array of nine anemometers were used to examine the turbulence in the flow into the array. Current design efforts use longitudinal turbulence models in which it is assumed that the blade averages the flow, so that the 
examination of the longitudinal turbulence structure, represented by the single "hub" anemometer (Case 1), was necessary for comparison purposes. Furthermore, since the use of a single anemometer is the most common measurement mode, the central hub anemometer was used as a bench mark against which all other analyses were compared.

The turbulence was also examined by arithmetically averaging the nine anemometers and considering the single value as characteristic of the entire expanse of the array. The analysis used unweighted averages and included the hub anemometer. Since the lift is generated by the outer portions of the turbine blades rather than the center, a weighting process may be more appropriate, but the relative merit of any weighting scheme is debatable and in the context of this report will not be addressed. The turbulence analysis based on the array average was compared to that for the hub anemometer and differences were noted.

The nonuniform structure of the flow field with respect to the disc of rotation of the hypothetical, large horizontal axis wind turbine was studied by examining the wind field synthesized from actual data from the circular array of anemometers. A synthesized wind that would impinge on a rotating blade is constructed by sampling the multichannel data records sequentially around the array. The data string thus constructed is a sequence of the actual winds as though observed at some point on the hypothetical blade(s). The synthesized winds have been analyzed in two modes; as though experienced by an independent element of a "soft" blade, and also by an average of the wind at both blades, to examine what a rigid blade might experience.

The flow encountered by either element of a' "soft" blade was simulated by the synthesized wind field to indicate what loading each blade might experience independently. For the case of a rigid blade which smooths the flow, the primary and 
complementary blade tip wind observations are merely averaged. The data are then analyzed and the results compared to the "soft" blade case and the single anemometer case. The rotation rate of the hypothetical blade can be controlled by lagging the samples around the circular array. The analysis in this report was performed using a rotation rate of $75 \mathrm{rpm}$.

\subsection{PRELIMINARY RESULTS AND COMPARISONS}

To examine the differences in the turbulent flow field for the four cases identified above, samples from the data records were analyzed as follows:

a) Sample Traces -- time sequence plots of the longitudinal wind component.

b) Spatial Correlations -- correlations of observations between the hub and the tip anemometers and between opposing tip anemometers.

c) Frequency Distributions -- analysis of $u, \Delta u / \Delta t$ and $\Delta \theta / \Delta t$ in terms of frequency distributions and cumulative frequency distributions of occurrences.

d) Power Spectra -- analysis in the frequency domain.

In the following discussion/comparison analysis modes, hub anemometer data are used as a single-point analysis bench mark. Data for the hub anemometer exhibit the following characteristics:

$\begin{array}{lrl}\text { Mean Wind Speed: } & \overline{\mathrm{s}}=4.85 \mathrm{~m} / \mathrm{s} \\ \text { Standard Deviation: } & \sigma_{\mathrm{S}}=1.23 \mathrm{~m} / \mathrm{s} \\ \text { Turbulent Intensity: } & \mathrm{I}_{\mathrm{T}}=\sigma_{\mathrm{S}} / \overline{\mathrm{s}}=0.25 \\ & \begin{array}{l}\text { Mean Wind Direction: } \\ \text { Standard Deviation: }\end{array} & \bar{\theta}=300.2^{\circ} \\ & \sigma_{\theta}=13.9^{\circ} \\ \text { Mean u-Component: } & \overline{\mathrm{u}}=4.68 \mathrm{~m} / \mathrm{s} \\ \text { Standard Deviation: } & \sigma_{\mathrm{u}}=1.25 \mathrm{~m} / \mathrm{s}\end{array}$


The temperature differences between $12.19 \mathrm{~m}$ and $36.58 \mathrm{~m}$ resulted in lapse rate, $\gamma=-0.03^{\circ} \mathrm{C} / 100 \mathrm{~m}$, which according to Nuclear Regulatory Commission (NRC) Guide 1.23 indicates a slightly stable condition. However, $\sigma_{\theta}$ at the hub indicated a neutrally stable condition. This lack of agreement is not common and merely implies that a neutral to slightly stable condition existed.

\subsubsection{Sample Traces}

Sample traces are presented for the array average (Case 2, Fig. 2), for the blade average (Case 4, Fig. 3), and for the single blade tip (Case 3, Fig. 4), superimposed on similar data for the hub anemometer (Case 1). Figure 2 shows that the array average trace is much smoother than that of the hub. This is because the array averaging acts as a low-pass spatial filter.

The array velocity fluctuation $U_{A}^{\prime}$ is the average of instantaneous fluctuations at each anemometer. An examination of 10-minute averages has revealed that the mean at the hub is representative of the mean of the array average. (I)

Using the synthesized wind to depict the flow into a rotating turbine blade, Fig. 4 reveals the small-scale turbulent structure. The fluctuations in the flow as would be felt by an individual WECS blade are much stronger than at the hub. While a periodic fluctuation at $0.8 \mathrm{sec}$ due to the mean profile structure is evident, there are also fluctuations which indicate the nonuniform structure of the small-scale turbulence at the various anemometers along the circle of rotation. Such fluctuations (as revealed in Fig. 4) are indicative of the loads imposed on a turbine blade as it rotates through a wind field.

Figure 3 shows that the u-component velocity for the blade-average fluctuates more rapidly than does the velocity 
at the hub, but is indeed smoothed when compared with that at the individual blade tip. Figure 3 also reveals a cyclical oscillation of the blade average trace that is twice the rotation frequency due to the rotation of the hypothetical blade set through the shear in the wind field. This results from averaging of the wind at the blades in the same angular configuration twice per rotation.

\subsubsection{Spatial Correlations}

The extent of the loading on a turbine rotor in a turbulent medium can be studied by examining how well the observations at various points in the array are correlated. Spatial correlations have been examined for each hub-blade tip position pair and for the complementary blade tip pairs (Fig. 5). Note the decrease in correlation with increasing distance and the change with angular position. There is a general increase in correlation with elevation, for both the longitudinal wind component and direction, which indicates a greater variability near the ground. The low value for the 1-2 pair of anemometers may be due to a decoupling in the boundary layer under the stable mountain drainage flow that existed during the observations. Further analysis is required before any conclusions can be drawn, but one may be able to infer the degree of representativeness of the hub anemometer in describing the wind field, or alternatively, the degree of coherence of the wind field across the span of the disc. It may ultimately be feasible to describe the dependence of these features on basic meteorological parameters.

\subsubsection{Frequency Distributions of Turbulence Parameters}

Fluctuations in the flow were examined by constructing:

a) the cumulative frequency distribution of velocity changes at several time lags $(\Delta u / \Delta t)$; and 
b) the cumulative frequency distribution of the directional differences at several time lags $(\Delta \theta / \Delta t)$.

Tabulated distributions were made for: 1) the hub, 2) the array average, 3) the blade average, and 4) the individual blades.

Gust Rise Statistics $(\Delta u / \Delta t)$

The frequency of a change in velocity, $\Delta u$, over a time period, $\Delta t$, is important for indicating the magnitude and frequency of loads on a blade element operating in a given wind field. $\Delta u / \Delta t$ is the change of velocity $(\Delta u)$ during a time $(\Delta t)$ and represents a gust over time $\Delta t$. It is analogous, but not equivalent, to examining the velocity changes and asking how fast change $\Delta \mathrm{u}$ occurs. Instead, we have asked, "In time interval $\Delta t$, what were the changes in velocity?" and then counted the observed changes $(\Delta u)$.

For the case of the hub anemometer, the cumulative frequency distribution of $\Delta u / \Delta t$, when analyzed for percentiles equivalent to one, two or three standard deviations of a normal distribution, exhibits an increasing spread for increasing $\Delta t$. That is, the fluctuation in velocity $\Delta u$ increases with $\Delta t$ (Fig. 6).

Examining the $\Delta \mathrm{u} / \Delta t$ distribution for the array average (Fig. 7), we see that various percentiles occur at much lower velocity changes than for the hub. The substantial difference indicates that the use of the array average statistics for gust rise rates results in considerable smoothing. The average over the disc is obviously not representative of the gusting that is occurring at each point in the disc.

Figure 8 is the $\Delta u / \Delta t$ distribution for the blade tip case (Case 3). The percentiles do not exhibit the same tendencies demonstrated by the single hub anemometer. In this case, spatial, as well as temporal, variations are evident in the flow field. The differences in the pattern would also depend 
on the rotation rate, but the uniformity in the pattern indicates a relationship that may be exploited for turbine design. A similar, but more compressed, pattern exists for the blade average case (Case 4), as illustrated in Fig. 9.

This evidence suggests that the spatial variations combined with the temporal variations to produce a nonuniform flow through the disc of rotation which cannot be represented by a single anemometer.

\section{Rate of Change of Direction $(\Delta \theta / \Delta t)$}

Figures 10 through 13 illustrate the rate of change of direction $(\Delta \theta / \Delta t)$ distribution for the same period of time used in analyzing velocity changes. The patterns of the percentile levels are similar to those for $\Delta u / \Delta t$, though not as uniform as in the case of the blade and blade-average. The spatial and temporal variations are evident and again indicate the inadequacy of a single anemometer measurement to describe the flow through the rotor disc.

\subsubsection{Power Spectral Estimates}

Power spectra were calculated for the hub, array average, blade average and blade tip cases. The calculation scheme used 15 minutes of $10 \mathrm{hz}$ data $(9000$ pts) and employed an International Math Sciences Library (IMSL) Fortran program to derive the spectral estimates for the autocorrelations. Interest in the power spectra has stemmed from design considerations of resonance frequencies and simulation schemes for atmospheric turbulence. In each case, the power spectral estimates for the hub anemometer were included as a bench mark to facilitate a comparison with single point turbulence spectra. In this initial analysis, the plots have not been normalized.

Comparing the spectra of the hub and the array average (Fig. 14), the effect of the averaging process is immediately 
obvious. Even though the high frequency tail is contaminated with noise, the sharper roll-off of the array spectra is evident.

Analysis of the rotating blade system reveals some other important results. In Figure 15, the power spectrum of the hub is compared to the power spectrum of the average of the two-blade elements. Note that a spike exists at $2.5 \mathrm{hz}$, which is twice the rotation frequency for a blade rotating at $75 \mathrm{rpm}$. This spike can be attributed to the half-rotation similarities resulting from the average of the two blades in the wind field.

Similarly, analysis of the single rotating blade revealed spikes in the power spectrum at $1.25 \mathrm{hz}$ and also at the higher harmonics (Fig. 16). These spikes are due to the rotation of the blade through vertical shear in the wind field. 


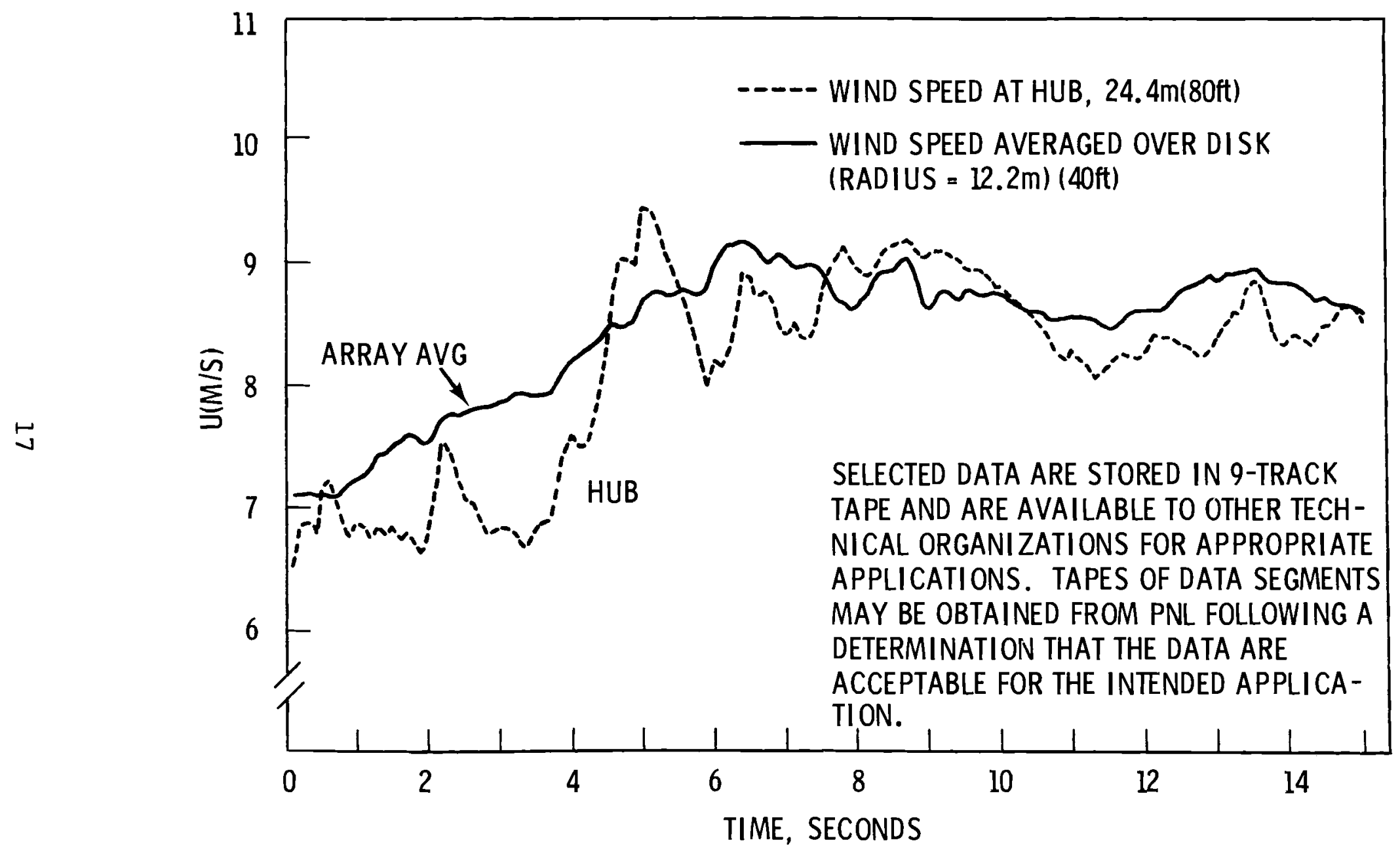

Figure 2. Trace of the Longitudinal wind Component, Hub Versus Array Average 


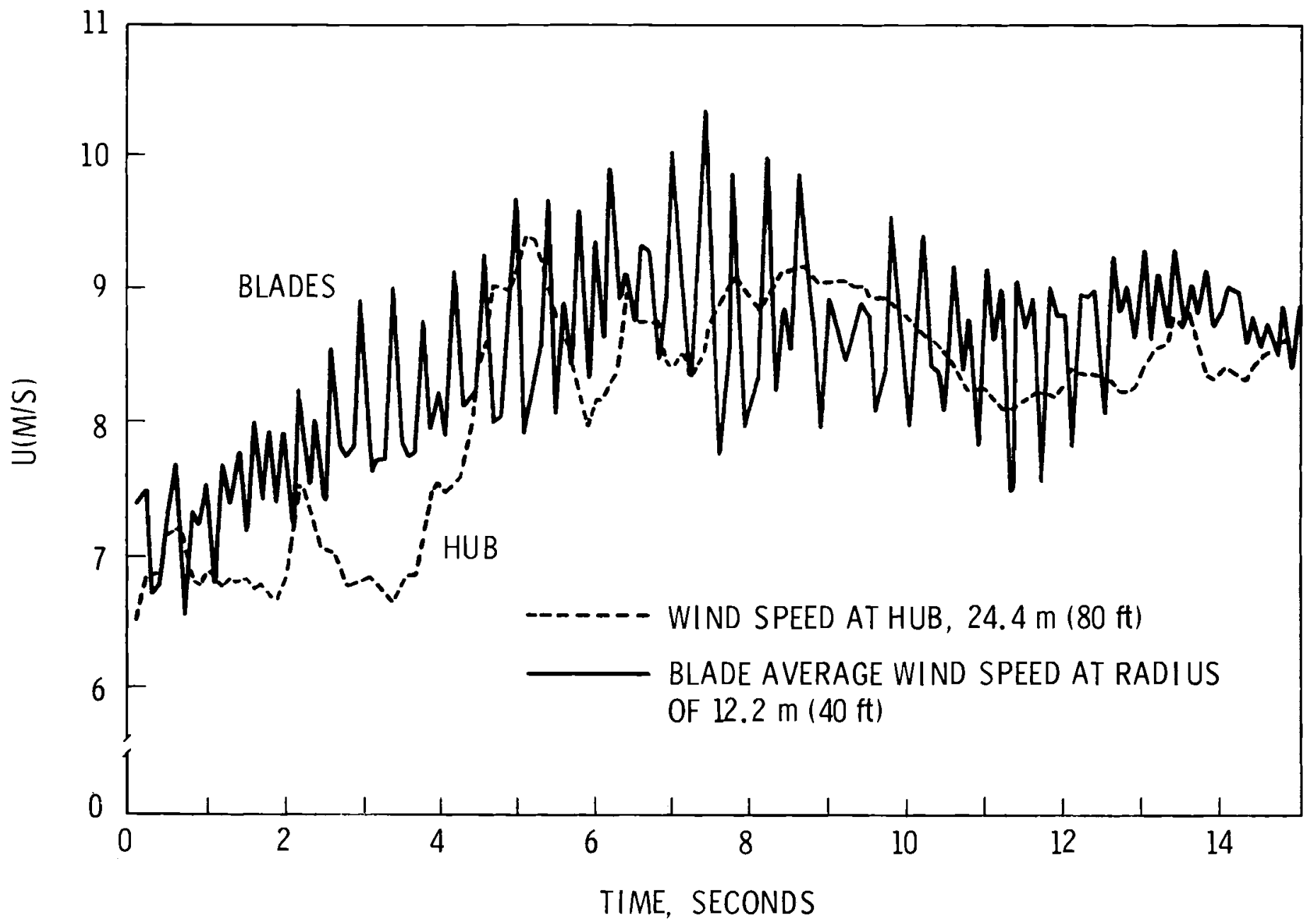

Figure 3. Trace of the Longitudinal Wind Component, Hub Versus Blade Average 


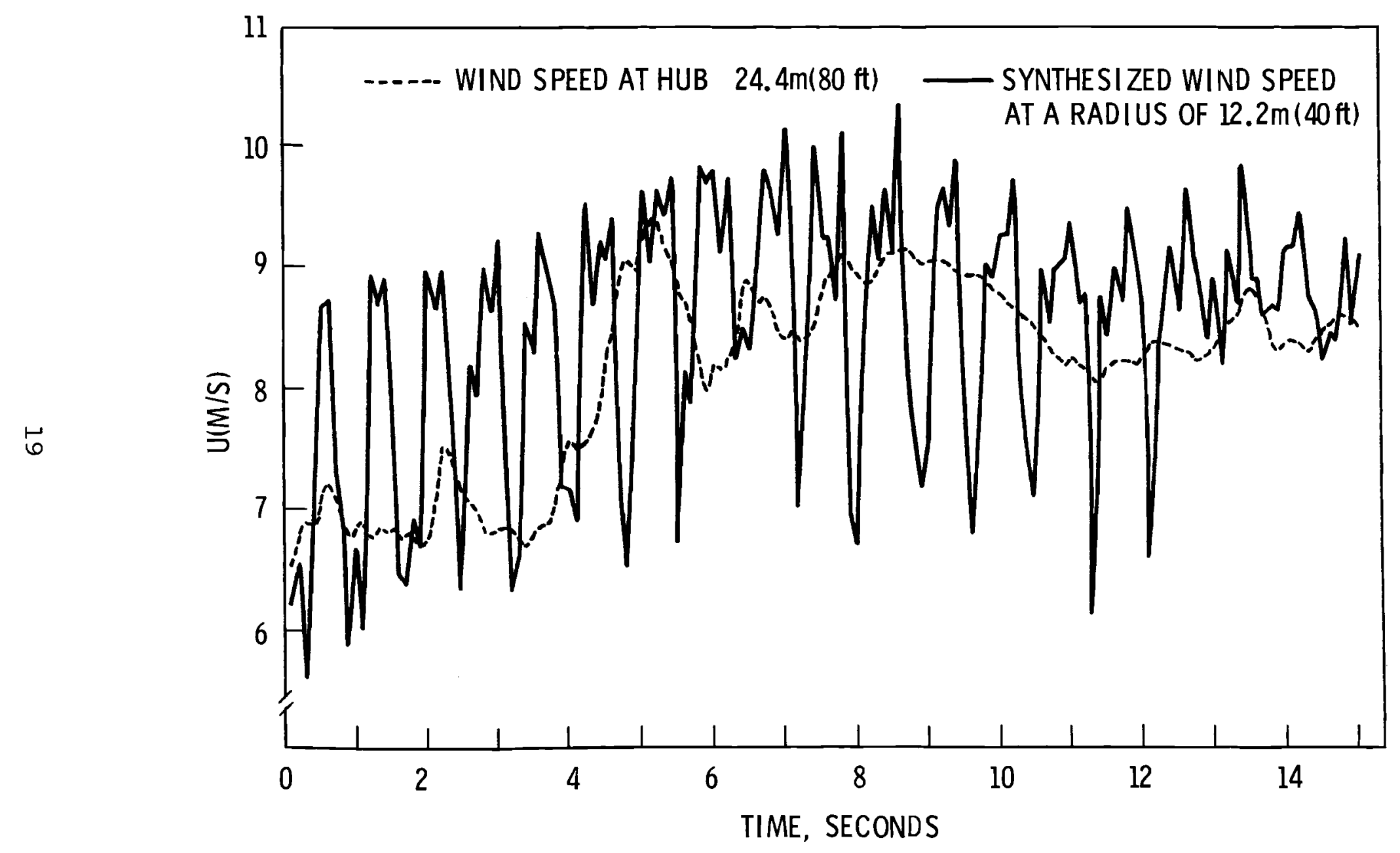

Figure 4. Trace of the Longitudinal Component 


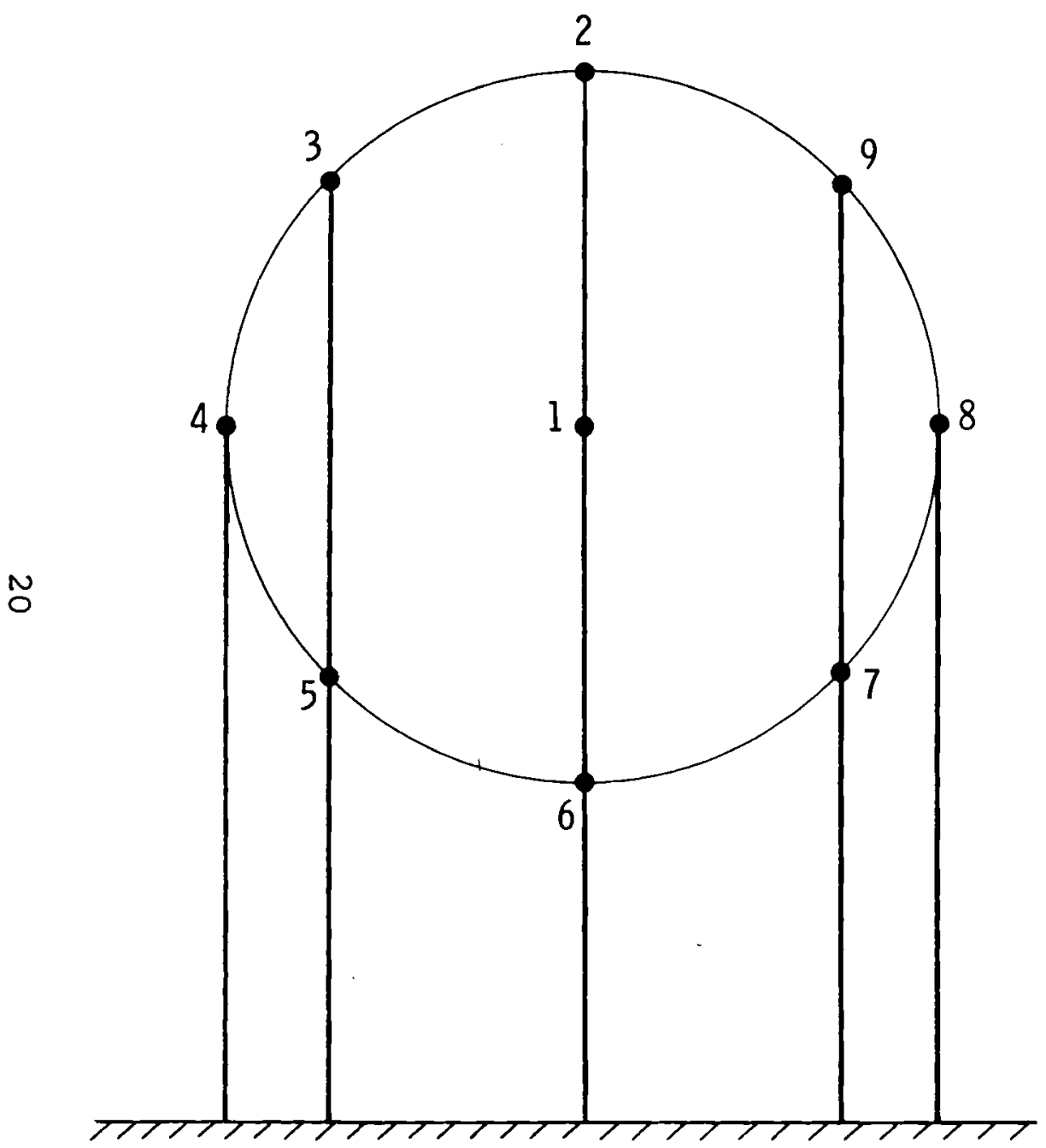

\begin{tabular}{|c|c|c|}
\hline $\begin{array}{c}\text { ANEMOMETER } \\
\text { PAIR }\end{array}$ & $R_{x y}(u)$ & $R_{x y}(\theta)$ \\
\hline $1-2$ & 0.918 & 0.777 \\
\hline-3 & 0.940 & 0.853 \\
\hline-4 & 0.937 & 0.842 \\
\hline-5 & 0.931 & 0.787 \\
\hline-6 & 0.877 & 0.643 \\
\hline-7 & 0.920 & 0.798 \\
\hline-8 & 0.927 & 0.845 \\
\hline-9 & 0.936 & 0.817 \\
\hline $2-6$ & 0.830 & 0.539 \\
\hline $3-7$ & 0.898 & 0.708 \\
\hline $4-8$ & 0.903 & 0.721 \\
\hline $5-9$ & 0.899 & 0.675 \\
\hline
\end{tabular}

Figure 5. Spatial Correlations Across the Array 


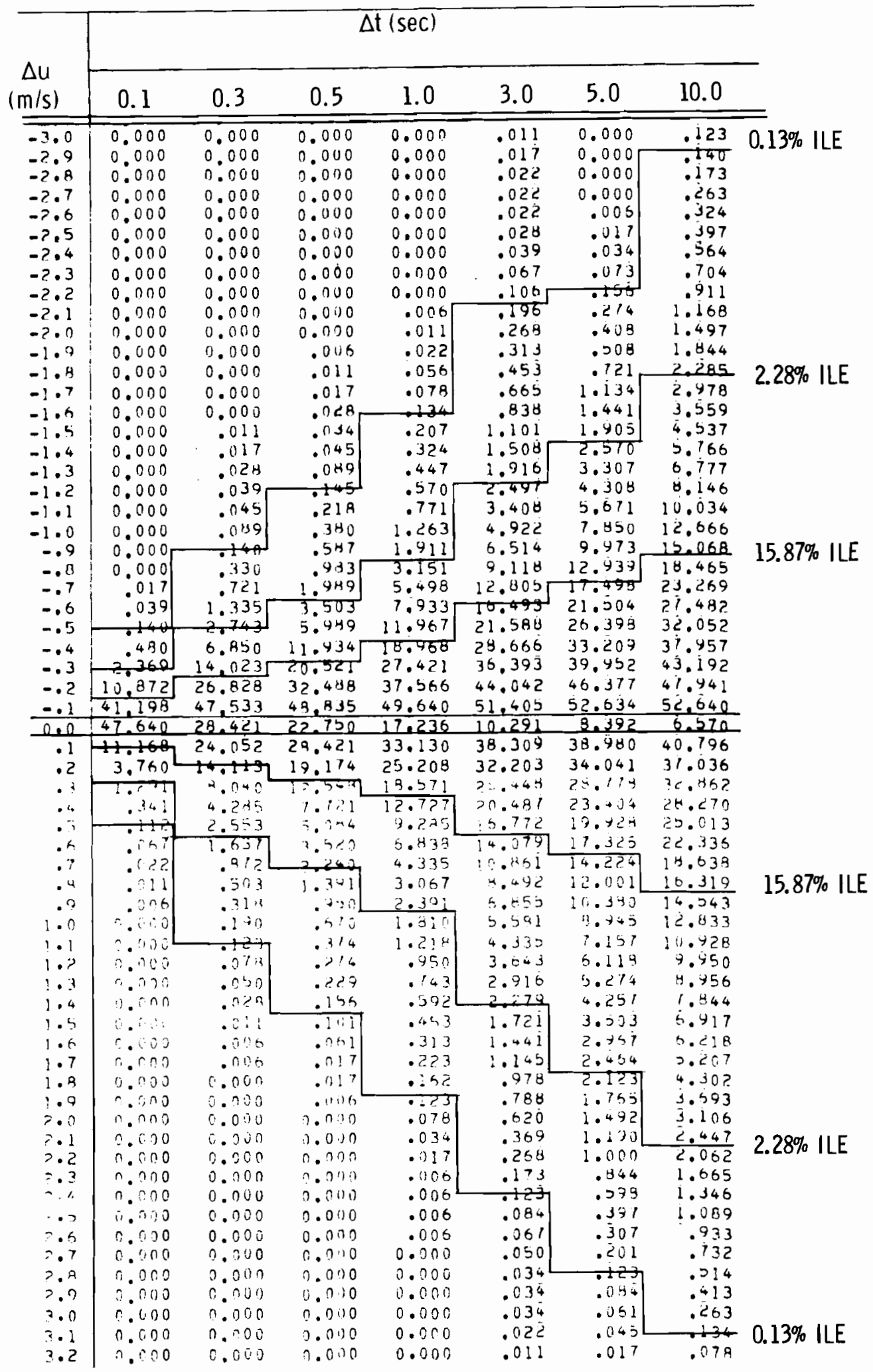

Figure 6. Cumulative Frequency Distribution of the Change in Velocity, $\Delta u$, in time $\Delta t$ for the HUB (Case 1) The percentile ( $\%$ ILE) levels are equivalent to the one, two and three standard deviation levels for a normal distribution. 


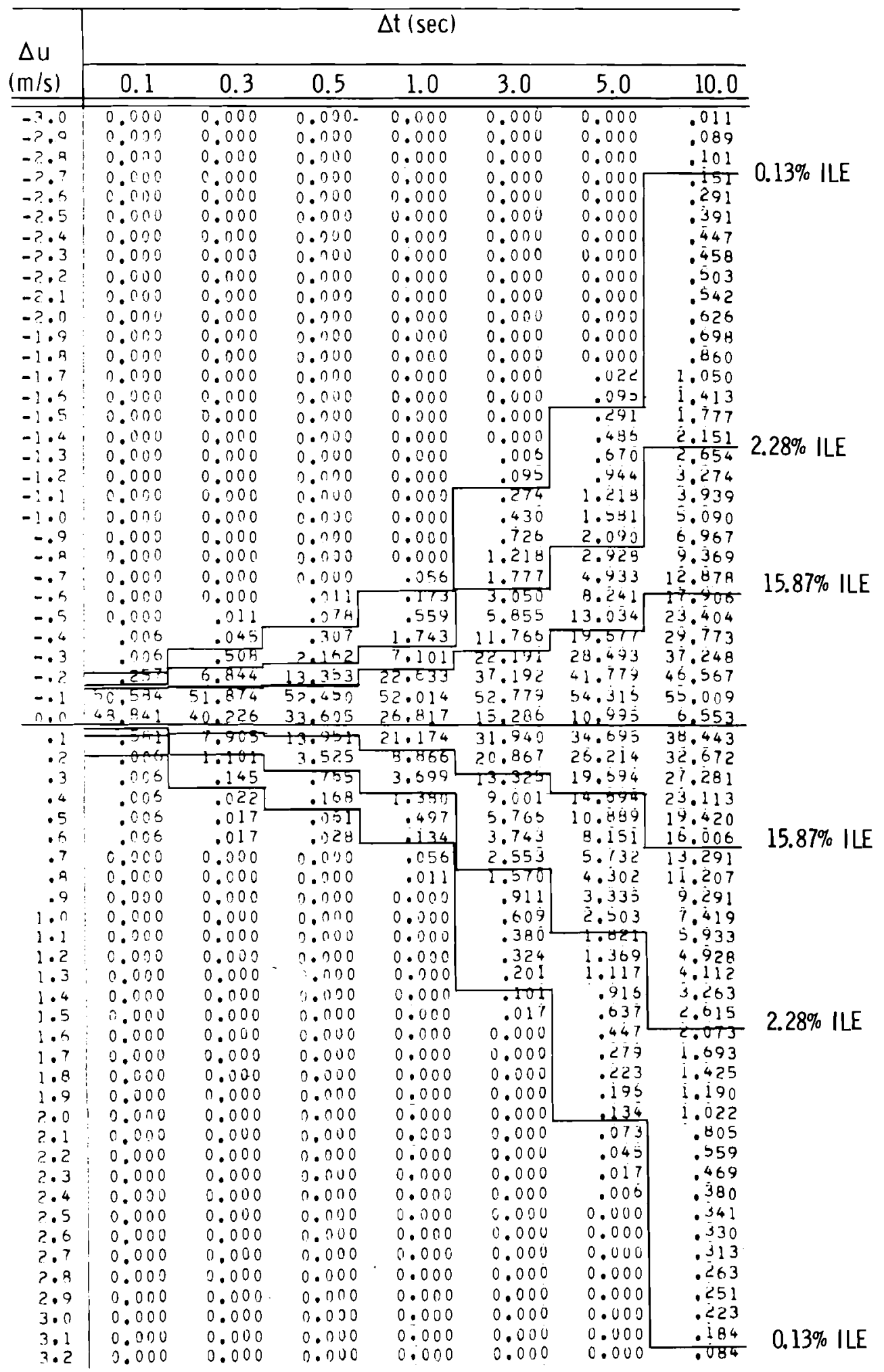

Figure 7. Cumulative Frequency Distribution of the Change in Velocity, $\Delta u$, in time $\Delta t$ for the ARRAY AVERAGE (Case 2) 


\begin{tabular}{|c|c|c|c|c|c|c|c|c|}
\hline \multirow{2}{*}{$\begin{array}{c}\Delta \mathrm{u} \\
(\mathrm{m} / \mathrm{s})\end{array}$} & \multicolumn{7}{|c|}{$\Delta t(\sec )$} & \\
\hline & 0.1 & 0.3 & 0.5 & 1.0 & 3.0 & 5.0 & 10.0 & \\
\hline-2.3 & $\overline{.117}$ & .045 & .047 & .056 & .061 & .095 & .251 & \\
\hline$=7.7$ & $\because 200$ & $.0 a_{4}$ & .0144 & . i) 05 & .073 &. $\begin{array}{lll}1 & 1 & 0 \\
1 & 0 & 5\end{array}$ & .291 & \\
\hline-2.1 & $.223 \mathrm{~L}$ & $\div+$ & . O45 & $.12 A$ & .101 & $1 \geq 3$ & .352 & \\
\hline-3.0 & 291 & .173 & $.11 \%$ & $1+4$ & .1175 & .131 & .464 & \\
\hline-7.9 & $.3 / 1$ & $.21 A^{1}$ & .151 & $.177^{\circ}$ & .190 & .173 & .520 & \\
\hline$\Rightarrow .9$ & .464 & .753 & 207 & .240 & .2 .3 & .245 & .026 & \\
\hline-7.7 & 415 & .374 & $\therefore 19$ & .397 & .285 & .341 & & \\
\hline-7.6 & .704 & .447 & .3 .35 & $.3 \cap 5$ & .352 & $.40 ?$ & .916 & \\
\hline$=.5$ & .916 & .442 & .4112 & .469 & .430 & .003 & 1.129 & \\
\hline$\because 44$ & $\therefore$ तिक & 0,047 & $.5+7$ & .650 & .603 & .710 & 1.548 & \\
\hline$-2 \cdot 3$ & 1.302 & .4 .17 & .513 & . HA? & .773 & .1244 & 1.049 & \\
\hline$\Rightarrow . ?$ & 1.507 & 0.47 & .744 & $1.16 ?$ & .450 & $1.11=$ & 2.179 & $2.28 \%$ ILE. \\
\hline$-2 \cdot 1$ & 1.911 & 1.179 & $1 \cdot \cap .49$ & $1=\sin 3$ & 1.260 & 1.557 & 2.165 & \\
\hline$-2 . n$ & 2,358 & 1.425 & 1.724 & 1.1655 & 1.554 & 1.415 & 3.402 & \\
\hline$-1 \cdot 3$ & 2.732 & 1.643 & $1 \cdot 520$ & 2.177 & 1.939 & ل & 4.024 & \\
\hline-1.7 & 3.257 & $? .050$ & 3.017 & $2.5 \times 1$ & لهب:3.2 & ?. 415 & 4.810 & \\
\hline-1.7 & $4.0 ; 3$ & 7.472 & 3.513 & $3.35 r$ & 3.140 & $3 .>03$ & 6.073 & \\
\hline$-1 \cdot 6$ & 4.576 & $\because 035$ & 7.811 & $3.75 \%$ & $3.7 \times 2$ & 4.173 & $7.1 S A$ & \\
\hline$-j \cdot \sqrt{1}$ & 5.704 & 3.088 & 3.712 & 4.799 & 4.710 & 5.207 & 0.766 & \\
\hline-1.4 & 7.039 & 4.072 & 5.01 & 6.034 & 5.934 & 0.454 & 10.632 & \\
\hline$-1 \cdot 3$ & $\therefore .330$ & 5.934 & 5.118 & 7.241 & 7.245 & 7.531 & 12.347 & \\
\hline-1.2 & 0.65 & 7.174 & 7. 340 & $8.77 i$ & 3.593 & $9.3 \times 2$ & 14.190 & 15 \\
\hline$-i \cdot i$ & $11: 32$ & B. Wh & $3.1<7$ & 10.570 & 10.470 & 13.245 & +64 & $15.81 \%$ ILE \\
\hline$-1 \cdot 0$ & 14.145 & 11.191 & 11.954 & 13.1 is & 12.705 & 14.090 & 19.593 & \\
\hline-.8 & 19.391 & $\frac{13 \cdot 247}{13044}$ & & $\frac{15.25 \%}{18.107}$ & $\frac{13.3425}{19.604}$ & 19.550 & $\begin{array}{l}22.159 \\
20.348\end{array}$ & \\
\hline. .7 & $=3.247$ & 20.308 & 20.577 & 21.761 & 22.852 & 23.793 & 24.409 & \\
\hline-.6 & 26.929 & 23.516 & $24.1 n 3$ & $? 5.085$ & 25.443 & 27.533 & 32.873 & \\
\hline-.5 & 31.859 & $34.4 \mathrm{Kl}$ & 20.611 & ?. 905 & $31.61=$ & 37.041 & 36.737 & \\
\hline-.4 & 34.516 & 34.147 & 33.710 & $34 \cdot 2 \cdot 25$ & 36.225 & 37.165 & 40.812 & \\
\hline-.3 & $41.33 \mathrm{H}$ & 39.561 & 34.902 & 37.354 & 41.321 & $42.1<0$ & 44.913 & \\
\hline-.2 & $45.57 ?$ & 44.332 & $43.3>9$ & 44.075 & 45.880 & 46.505 & $4 \hat{\theta} .455$ & \\
\hline-.1 & 40.930 & 49.355 & 49.327 & 49.997 & 50.623 & 51.293 & 52.031 & \\
\hline$n$ & +470 & 7.224 & 7,744 & 7.743 & 7.140 & 5.520 & 4.939 & \\
\hline .1 & 43.506 & 43.427 & $47.4+5$ & 43.205 & 42.237 & $42.17 ?$ & 43.036 & \\
\hline .2 & 39.974 & $3 \because .801$ & $32.0 \% 7$ & 38.773 & 37.913 & 34.203 & 39.784 & \\
\hline .3 & 24.907 & 33.862 & 33.778 & 34.075 & 33.471 & 33.773 & 36.572 & \\
\hline .4 & 30.320 & 29.180 & 27.911 & $2 n .8 \cap 0$ & 29.841 & 29.254 & 32.746 & \\
\hline .5 & 36.477 & $? 3.957$ & 23.538 & 24.834 & 75.398 & 25.324 & 30.113 & \\
\hline .4 & 33.728 & 27.532 & $17.92 \pi$ & $21.7 \cap 5$ & $2 ? .443$ & 22.453 & 27.583 & \\
\hline .7 & $=0.001$ & 16.733 & is lo? & 17.355 & 19.001 & 19.579 & 24.320 & \\
\hline. $\mathrm{H}$ & 16.874 & 13.984 & $13.420^{2}$ & 15. हाया & 15.240 & 17.335 & 21.094 & \\
\hline .9 & דיר.5. & 11.305 & 11.341 & 13.034 & 14.191 & 14. ग्रार & 19.183 & \\
\hline 1.0 & 17.950 & 7.704 & 0.300 & 11.263 & 12.325 & 13.017 & 17.733 & \\
\hline 1.1 & 10.576 & 7.464 & 7.353 & 8.883 & 9.945 & 10.5601 & +5.073 & $1587 \%$ \\
\hline 1.2 & 0.005 & 6.319 & 5.135 & 7.637 & 9.632 & $9.4 ? 0$ & 13.677 & \\
\hline 1.3 & $7.74 n$ & 5.118 & $=.145$ & $6.4]_{4}$ & 7.246 & 3.174 & 12.353 & \\
\hline 1.4 & 5.179 & 4.095 & $6.7 / 4$ & 5.229 & $5.76 !$ & 7.051 & 10.811 & \\
\hline 1.5 & 5.324 & $3 \cdot 25 ?$ & $3 \cdot 332$ & 4.330 & 4. HE I & 6.012 & 9.648 & \\
\hline 1.6 & 4.470 & $2.57 \mathrm{~s}$ & 3.472 & 3.503 & 4.123 & 5.179 & 5.704 & \\
\hline 1.7 & $3.5 ? 7$ & $\div 173$ & 1 & ?.839 & $3.4 \div 5$ & 4.331 & 1.526 & \\
\hline 1.9 & 7.840 & 1.593 & 1.911 & $2.35,3$ & 2.321 & 3.53 & 0.732 & \\
\hline$\therefore 9$ & $? .475$ & 3.374 & 1.515 & 2.345 & 2.313 & 3.153 & 5.017 & \\
\hline & 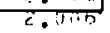 & 1.155 & $1.7 n 8$ & 1.721 & 2.305 & 2.755 & 3.425 & \\
\hline $2 \cdot 1$ & 1.559 & .943 & 1.125 & 1.307 & 1.531 & 2.113 & 4.609 & \\
\hline $7 . ?$ & 3.335 & .143 & .711 & $1 . i 1.5$ & $1.240^{2}$ & $1 .+1$ & .090 & \\
\hline$\therefore 3$ & $1: 151$ & .515 & ina & .73 & 1.050 & 1.537 & 3.049 & \\
\hline$? .4$ & .412 & .453 & .5 .13 & $\therefore$ & .93 & ذ1: 20. & 3.145 & \\
\hline & .542 & .360 & $.4 \neq 7$ & .453 & .726 & 1.034 & 2.710 & \\
\hline 2.6 & .500 & .270 & . & .320 & .515 & .964 & $2.35 \%$ & $2.28 \%$ ILE \\
\hline 7.7 & 471 & .235 & . & $.3 \cap 7$ & .486 & .533 & 1.944 & \\
\hline ?. & 302 & .154 & .120 & $.2=9$ & .391 & $.34 \mathrm{~A}$ & 1.693 & \\
\hline$? .9$ & $.2<8$ & 16 ? & .170 & .201 & 313 & .475 & 1.441 & \\
\hline 3.2 & $1 \% 6$ & .035 & 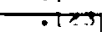 & $114 ?$ & .246 & .417 & 1.2224 & \\
\hline 7.1 & .151 & .067 & - Ans & . गा? & .100 & $.3 / 41$ & .978 & \\
\hline 7.7 & لحنج] & .007 &.$n 51$ & .0731 & 1 & .251 & .855 & \\
\hline 7,3 & .105 & .037 & . $n 19$ & .061 & .117 & $.23 j$ & .760 & \\
\hline
\end{tabular}

Figure 8. Cumulative Frequency Distribution of the Change in Velocity, $\Delta \mathrm{u}$, in time $\Delta t$ for a single BLADE (Case 3) 


\begin{tabular}{|c|c|c|c|c|c|c|c|c|}
\hline \multirow{2}{*}{$\underset{(\mathrm{m} / \mathrm{s})}{\Delta \mathrm{u}}$} & \multicolumn{7}{|c|}{$\Delta t(\mathrm{sec})$} & \\
\hline & 0.1 & 0.3 & 0.5 & 1.0 & 3.0 & 5.0 & 10.0 & \\
\hline $\begin{array}{l}-3 \cdot 1 \\
-7 \cdot r\end{array}$ & ?. & n.olin & 0.0190 & 0.000 & 0.000 & 0.000 & .101 & $0.13 \%$ ILE \\
\hline$-?$ & nono & 0.1000 & nno & $0.0 \cap 8$ & a. una & $\begin{array}{l}n .000 \\
0.000\end{array}$ & is & \\
\hline$-i \cdot k$ & 0.1108 & nonon & $n .1110$ & 0.000 & $0.0 \cap 0$ & 0.000 & .212 & \\
\hline-7.7 & a. ons & $n .000$ & 0.1100 & $0 . \cap \cap C$ & 0.000 & .005 & .268 & \\
\hline-7.6 & 0.000 & 0.000 & $\therefore 0.110$ & $0.0 \cap C$ & $0 . \therefore: 00$ & $.03 \%$ & .296 & \\
\hline$\rightarrow .5$ & . r115 & 0.000 & 0.0100 & $0.0 \cap C$ & 0.500 & $.0 .3 i$ & .346 & \\
\hline-7.6 & $.3 \pi$ & .013 & ona & $.0 \cap E$ & .006 & .056 & .464 & \\
\hline$-7 \cdot 3$ & .000 & .011 & .0186 & - actet. & .011 & .073 & .603 & \\
\hline$-7 \cdot ?$ & .011 & .017 &. & - unt & $.02 ?$ & $.11 ?$ & .726 & \\
\hline-7.1 & $0 ! 7$ & $.02 \overline{6}$ & . nen & .006 & .045 & $.1>9$ & .844 & \\
\hline$-\gamma \cdot r$ & .074 & .035 & .014 & .097 & $. \cap 6>[$ & .144 & $.9 \in 7$ & \\
\hline$-1 \cdot c$ & . chl & . n57 & . nun & .028 & .106 & .244 & 1.156 & \\
\hline$-1 \cdot n$ & . $\cap 5.4$ & .117 & .078 & .06 .7 & .102 & .314 & 1.363 & \\
\hline-1.7 & كسيس]. & $.1 \times 4$ & .112 & .170 & $.2+5$ & $.53 !$ & 1.059 & \\
\hline-1.6 & .22 .3 & $.79 !$ & $.17 \%$ & .835 & .453 & .721 & 1.961 & \\
\hline$-1 \cdot 5$ & $.33 n$ & .613 & .201 & .352 & .637 & .913 & 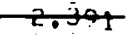 & $2.28 \% 1 \mathrm{LL}$ \\
\hline-1.4 & .553 & .6 .31 & .508 & .564 & $.8 B E$ & $1.40 \mathrm{~s}$ & 2.983 & \\
\hline$-1 . ?$ & . & .067 & .740 & . $9: \leq$ & 1.251 & 1.094 & 3.676 & \\
\hline$-1 \cdot \bar{\varepsilon}$ & 1.270 & 1.525 & 1.757 & 1.451 & 1.916 & ل & $4.6 P ?$ & \\
\hline$-1 .:$ & $1.87 \%$ & & $1 . \mu+3$ & $\therefore$ in? & له.. & 3.451 & 5.933 & \\
\hline$-1 \cdot 0$ & 2.077 & $3.34 i$ & 3.749 & 3.173 & 3.537 & 4.749 & $7 . H G G$ & \\
\hline-.0 & 4.313 & 5.011 & $4.5 / 22$ & 4.771 & 5.363 & 6.549 & 10.330 & \\
\hline-.9 & 4.757 & 6.932 & 5.54 .3 & 5.53: & 7.100 & 8.472 & 13.179 & $15.87 \%$ \\
\hline-.7 & 3.55 .7 & 10.263 & $0.7 \cdot 3$ & 9.730 & 9.911 & 16.254 & T!.टपा & \\
\hline-.6 & 1.7 .5 .25 & 14.034 & $12.4 \times 7$ & $1 \mathrm{c} \cdot 54 \mathrm{Fa}$ & $13.48,7$ & 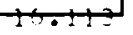 & 21.459 & \\
\hline-.5 & $14.45 \pi$ & 73.141 & T'. & 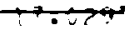 & T3. उदर & 2.1 .141 & 26.862 & \\
\hline-.4 & >7.29 & 26.737 & 77.7 .1 & 23.772 & 25.6319 & $2 E .367$ & 33.197 & \\
\hline.- .3 & $7 / 4.35 .4$ & 33.353 & $24.2>0$ & 20.005 & 23.561 & 35.751 & 39.343 & \\
\hline.$- ?$ & $42.651)$ & 41.550 & $4 ? .056$ & 40.074 & 42.413 & 44.455 & 66.624 & \\
\hline.$- i$ & 40.947 & 46.910 & $5 n .04 \%$ & 50.271 & 51.143 & 52.042 & 52.841 & \\
\hline$\therefore$. & 4.453 & 4.481 & $0.79 ?$ & 9.994 & 9.107 & 7,194 & $0.34 \%$ & \\
\hline$\overline{.1}$ & $41.65 i$ & $4 \hat{c} .4115$ & $4 ! .611$ & $36.75:$ & $=9.758$ & 40.170 & 40.818 & \\
\hline .7 & 37.36 & $34.0^{846}$ & 33.270 & $30.6,05$ & 31.253 & $3 \hat{c} .734$ & 35.203 & \\
\hline .3 & 24.479 & 26.962 & $25.14 i$ & 24.058 & $25.05 \%$ & 27.035 & 30.672 & \\
\hline .4 & $19.1,74$ & $i^{c} .655$ & 19.109 & 17.817 & 19.012 & $21 . .370$ & 25.78 .9 & \\
\hline .5 & Ha. & 14.474 & 14.64 & $13.5 n 4$ & 7 & 17.504 & 22.275 & \\
\hline .5 & $\ln .0 \operatorname{sic} 4$ & 9.637 & $1 n .724$ & D.Sn? & 11.202 & 13.575 & 18.481 & \\
\hline .7 & 7.06 .7 & 6.267 & 7.7 .45 & $6 . \leqslant 03$ & 8.542 & $10.721 \mathrm{~L}$ & 15,253 & $15.87 \%$ ILE \\
\hline مִ م. & 5.15. & 4.335 & 5.211 & 4.2 .44 & 3.665 & 4.509 & 12.906 & \\
\hline .5 & 3.436 & 2. ERA & $3 . 6 \longdiv { 5 }$ & 3.235 & 4.860 & 6.549 & 10.783 & \\
\hline 1.0 & 7.435 & (1) & $2.54 B$ & $2.44 ?$ & 3.515 & $5.61 !$ & 9.123 & \\
\hline 1.1 & 1.603 & $1.3^{0}:$ & 1.550 & 1.76 & 2.643 & 3.889 & 7.531 & \\
\hline 1.2 & 1.1067 & .944 & $\because 0 \leq n$ & 1.112 & 1.05 & 3.073 & 6.241 & \\
\hline$! \cdot 3$ & .576 & $.42 r$ & .715 & .816 & $\therefore .251$ & 2.475 & 5.246 & \\
\hline 1.4 & .300 & .374 & .448 & . En ? & $.92 i^{\prime}$ & 1.344 & 4.363 & \\
\hline 1.5 & $.2 \times 5$ & $.1+4$ & .341 & .341 & .670 & 1.542 & 3.715 & \\
\hline 1.6 & .179 & ?231 & .125 & .190 & .436 & 1.179 & 3.078 & \\
\hline 1.7 & لججخج. & .078 & .111 &.$T \mathrm{TC}$ & .274 & .583 & 2.570 & \\
\hline $3 \cdot 9$ & . 0109 &.$\cap \supset f$ &. $\operatorname{lng} 7$ & .050 & .198. & $.642^{2}$ & से & $2.28 \% 1$ \\
\hline 1.0 & .074 & .034 & .1118 & $.5,25$ & .100 & .441 & 1.838 & \\
\hline 2.0 & . n:? & .022 & 0 . $₫$ ? & $.0 ! 2$ & $\ldots .073$ & .291 & 1.564 & \\
\hline $2 \cdot i$ & $.00 \%$ & . inct & .011 & - Cong & .034 &. .95 & 1.246 & \\
\hline ?.? & .006 &.$\cap 0 \theta_{2}$ & - ning & $0.0 n 0$ & . ก?2 [ & .151 & 1.011 & \\
\hline 7.3 & 0.0 & .006 & $.60 \mathrm{~A}$ & 0.000 & .017 &. $\cos 3$ & .860 & \\
\hline 2.4 & $n .000$ & .000 & $n .0 n 0$ & 0.000 & .011 & $.0 ? 3$ & .710 & \\
\hline 7.5 & 0.00 & . riog & 0.000 & $0.0 n c$ & .011 & .051 & .570 & \\
\hline 2.6 & 0.000 & - ricit & 0.0110 & $0 . c \cap 0$ & 0.000 & .050 & .492 & \\
\hline 2.7 & 0.000 & .006 & $n .0 \cap 0$ & 0.1100 & 0.000 & .045 & .385 & \\
\hline$? .8$ & 0.000 & 0.000 & 0.000 & 0.000 & $c .000$ & .045 & .341 & \\
\hline 2.9 & 0.000 & 0.000 & n. $0 \cup 0$ & 0.000 & 0.000 & .0 .34 & .291 & \\
\hline 3.0 & $n . \cap \cap 0$ & $0.00 n$ & 0.1100 & $0.1: 00$ & 0.000 & $.01 \mathrm{i}$ & $.24 t$ & \\
\hline 3.1 & 0.000 & 0.000 & 0.000 & $0 . \cos$ & 0.000 & .012 & .179 & \\
\hline 3.2 & 0.000 & 0.000 & $r .0110$ & $0.0,00$ & 0.000 & . $\left.\begin{array}{lll}1 & 1\end{array}\right]$ & .165 & U. \\
\hline
\end{tabular}

Figure 9. Cumulative Frequency Distribution of the Change in velocity, $\Delta u$, in time $\Delta t$ for the BLADE AVERAGE (Case 4) 


\begin{tabular}{|c|c|c|c|c|c|c|c|c|}
\hline \multirow{2}{*}{$\Delta \theta$} & \multicolumn{7}{|c|}{$\Delta t(\mathrm{sec})$} & \\
\hline & 0.1 & 0.3 & 0.5 & 1.0 & 3.0 & 5.0 & 10.0 & \\
\hline $\begin{array}{l}-39.0 \\
-39.0\end{array}$ & $\begin{array}{l}0.000 \\
0.000\end{array}$ & $\begin{array}{l}0.000 \\
0.000\end{array}$ & $\begin{array}{l}0.000 \\
0.000\end{array}$ & $\begin{array}{l}0.000 \\
0.000\end{array}$ & $\begin{array}{l}0.000 \\
0.000\end{array}$ & .045 & $\frac{123}{151}$ & $0.13 \%$ ILE \\
\hline$-37,0$ & 0.000 & 0.000 & 0.000 & 0.000 & 0.000 & .057 & .151 & \\
\hline-36.0 & $0.0 \bigcirc 0$ & 0.000 & 0.000 & 0.000 & .0065 & لك+14 & .218 & \\
\hline-35.0 & $\begin{array}{l}0.000 \\
0.000\end{array}$ & $\begin{array}{l}0.000 \\
0.000\end{array}$ & $\begin{array}{r}0.000 \\
0.000\end{array}$ & 0.000 & .005 & .212 & .235 & \\
\hline-36.0 & $\begin{array}{l}0.000 \\
0.000\end{array}$ & $\begin{array}{l}0.000 \\
0.000\end{array}$ & $\begin{array}{l}0.000 \\
0.000\end{array}$ & 0.000 & .017 & .235 & .268 & \\
\hline-33.0 & $\begin{array}{l}0.000 \\
0.000\end{array}$ & $\begin{array}{l}0.000 \\
0.000\end{array}$ & 0.000 & 0.000 & .022 & .235 & .291 & \\
\hline $\begin{array}{l}-32.0 \\
-31.0\end{array}$ & $\begin{array}{l}0.000 \\
0.000\end{array}$ & $\begin{array}{l}0.000 \\
0.000\end{array}$ & $\begin{array}{l}0.000 \\
0.000\end{array}$ & $\begin{array}{l}0.000 \\
0.200\end{array}$ & $\begin{array}{l}.022 \\
.028\end{array}$ & $\begin{array}{l}.330 \\
.335\end{array}$ & $\begin{array}{r}.352 \\
.480\end{array}$ & \\
\hline-30.0 & 0.000 & 0.000 & 0.000 & 0.000 & .056 & .330 & .559 & \\
\hline-27.0 & 0.000 & 0.000 & 0.000 & 0.000 & .101 & .413 & .631 & \\
\hline$-2 R, 0$ & 0.000 & 0.000 & 0.000 & .006[ & .156 & .514 &.$\overline{777}$ & \\
\hline-27.0 & 0.000 & 0.000 & 0.000 & .022 & .229 & .570 & .950 & \\
\hline-26.0 & 0.000 & 0.000 & 0.000 & .028 & .274 & .692 & 1.123 & \\
\hline-75.0 & 0.000 & 0.000 & 0.000 & .045 & .374 & .737 & 1.279 & \\
\hline-26.0 & 0.000 & 0.000 & & . U5? & .497 & .944 & 1.542 & \\
\hline-23.0 & $\begin{array}{l}0.000 \\
0.000\end{array}$ & $\begin{array}{l}0.000 \\
0.000\end{array}$ & $\begin{array}{r}0.000 \\
.006\end{array}$ & .067 & .620 & .993 & 1.793 & \\
\hline $\begin{array}{l}-2 ? .0 \\
-21.0\end{array}$ & 0.000 & 0.000 & .006 & $\begin{array}{l}.073 \\
.089\end{array}$ & $\begin{array}{r}.782 \\
.944\end{array}$ & $\begin{array}{l}1.145 \\
1.307\end{array}$ & $\frac{2.090}{2.453}$ & $2.28 \%$ ILE \\
\hline-20.0 & 0.000 & 0.000 & .006 & .105 & 1.050 & 1.485 & 2.866 & \\
\hline-19.0 & 0,000 & 0.000 & .006 & $\because 40^{\circ}$ & 1.296 & 1.725 & 3.374 & \\
\hline-10.0 & 0.000 & 0.000 & .006 & .184 & 1.503 & 2.101 & 4.011 & \\
\hline-17.0 & 0.000 & 0.000 & .011 & .240 & 1.7715 & 2.453 & $\$ .821$ & \\
\hline-16.9 & 0.000 & 0.000 & .039 & - 390 & 2.162 & 2.493 & 3.242 & \\
\hline-15.0 & 0.000 & .006 & .013 & .464 & 2.564 & 3.537 & 6.537 & \\
\hline-14.0 & 0.000 & 011 & $.12 \mathrm{~B}$ & .615 & 3.039 & $4 . \bar{c} 75$ & 1.104 & \\
\hline-13.0 & 0.000 & 022 & .156 & .838 & $3.61 \mathrm{~J}$ & 5.207 & $\because .095$ & \\
\hline-12.0 & 0.000 & .039 & .212 & 1.050 & 4.414 & 6.219 & 10.293 & \\
\hline-11.0 & 0.000 & .073 & .346 & 1.492 & 5.458 & 7.472 & 12.007 & \\
\hline $\begin{array}{r}-10.0 \\
-0.0\end{array}$ & .011 & $\frac{.0 .118}{.001}$ & $\begin{array}{l}.542 \\
.810\end{array}$ & & $\begin{array}{l}0.5105 \\
8.593\end{array}$ & 9.107 & 14.247 & $15.87 \%$ ILE \\
\hline-0.0 & $\begin{array}{l}.0<2 \\
0405\end{array}$ & $\begin{array}{r}.801 \\
.369\end{array}$ & $\begin{array}{r}.910 \\
1.369\end{array}$ & $\begin{array}{l}2.944 \\
4.151\end{array}$ & $\begin{array}{r}8.593 \\
10.654\end{array}$ & 11.017 & TH.07 & \\
\hline-7.0 & 101 & 698 & $\begin{array}{l}1.1013 \\
7.113\end{array}$ & $5.95 n$ & $\begin{array}{l}10.654 \\
13.510\end{array}$ & $\begin{array}{l}13.114 \\
15.650\end{array}$ & $\begin{array}{l}19.040 \\
21.534\end{array}$ & \\
\hline$-h \cdot 0$ & .212 & 1.4585 & 3.492 & 8.235 & $16,06+5$ & 19.407 & 20.292 & \\
\hline-5.0 & 469 & 2.735 & 5.715 & 11.755 & 21.007 & 24.253 & 20.918 & \\
\hline$-4 \cdot 0$ & 1.129 & 5.302 & $9.721 \mathrm{I}$ & $18.7 \times 9$ & 26.225 & $29.6>0$ & $3 j .1 \cap B$ & \\
\hline$-7 . n$ & अ. Tरू & 11.075 & to.t. & 24.649 & 32.653 & 35.896 & 30.337 & \\
\hline$-2 \cdot 0$ & $\frac{10.330}{43.583}$ & $\begin{array}{l}23.666 \\
47.612\end{array}$ & $\begin{array}{l}79.4119 \\
49.617\end{array}$ & $\begin{array}{l}35.494 \\
49.355\end{array}$ & $\begin{array}{l}41.019 \\
48.801\end{array}$ & 42.053 & 41.593 & \\
\hline$\frac{-1.0}{c .0}$ & 45,600 & $26,94 n$ & 22,169 & 15.079 & $\frac{48,801}{9,095}$ & $\frac{44.515}{7.171}$ & $\frac{45,533}{5,112}$ & \\
\hline 1.7 & $70.73=$ & 23.656 & 27.706 & 35.072 & 42.133 & 4.1 .723 & 45.340 & \\
\hline 2.9 & $2.44+$ & 1.34 & $17.34 ?$ & 24.764 & $23.4 n 3$ & 37.145 & $41.1 \in 4$ & \\
\hline 3 & .411, & 3.233 & 3.795 & $1 ; .2+1$ & $\rightarrow$ an! & $30 \cdot 135$ & 30.180 & \\
\hline 6.7 & L ל: & 2.53 .7 & 5.320 & $i 1.437$ & $21 .-31$ & $21 . x=$ & $32.12 ?$ & \\
\hline$\because . i$ & $\therefore 1$ & 1.3 .9 & 9.297 & $4 . ; 7$ & 13.3 .34 & $17.3=0$ & 20.074 & \\
\hline$\ddot{7}$ & $\therefore=0$ & $\cdot \rightarrow 1: L$ & {$[.+14$} & 5.927 & 13.254 & G & 2.141 & \\
\hline$? ?$ & .27 & $.3^{7} 4$ & $1.9 \times 7$ & $3 . \cdot 4 ?$ & 19.224 & $12 .+29$ & 14.454 & \\
\hline$\because \%$ & \begin{tabular}{cc|}
71 & 1 \\
0 & 0
\end{tabular} & .857 & .20 & 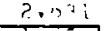 & $9.2 ! l$ & 10.23 & $12.2 \pi$ & $15.81 \%$ ILE \\
\hline$i$ & 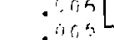 & .173 & $\begin{array}{l}.479 \\
340\end{array}$ & $\begin{array}{l}1.9 \\
1.3 \\
1.3\end{array}$ & $\begin{array}{r}5.291 \\
4.911\end{array}$ & $3, i r$ & 10.026 & \\
\hline $1 i$. & .034 & .047 & $\begin{array}{l}.340 \\
.214\end{array}$ &,,..+ & $\begin{array}{r}4.91 \\
.534\end{array}$ & $\begin{array}{l}6.73 \\
5.2=1\end{array}$ & $\begin{array}{r}10.042 \\
5.31 \pi\end{array}$ & \\
\hline $1>. ;$ & $.30 \mathrm{~h}$ & .050 & .267 & $.7 \div 1$ & $3 . \mathrm{CO}_{4}$ &. .414 & 0.1150 & \\
\hline$i^{2} .1$ & 6.00 .3 & 017 & $.1+2$ & $.523 L$ & 2.363 & $3.5 \mathrm{i}$ & 5.132 & \\
\hline 14 & 5.000 & C. $0: 0$ & .013 & .252 & $1.73 \%$ & 2.044 & -.199 & \\
\hline 15.0 & 0.707 & 0.003 & .1134 & .877 & $1.330 \mathrm{~L}$ & 2.61 & +.055 & \\
\hline $1=0$ & 0.050 & 9.07. & $.0<2$ & .247 & $\therefore .13:$ & 1.742 & 3.314 & \\
\hline 17.6 & $0 . \operatorname{mon}$ & $0.0 u r_{1}$ & .1111 & $\because ?$ & .733 & $1 . \div 1 ;$ & <. is & \\
\hline$i^{r} \cdot n$ & 0.000 & 0.030 & - 015 & .74 & .41 & $1.21+1$ & $E^{2} .441$ & $2.28 \%$ ILE \\
\hline $1 \% 0$ & ¿. J i ? & 0.0100 & 7.070 & $\because 11 \geqslant$ & $.71=$ & $1.77:$ & $2 . \sqrt{23}$ & \\
\hline $2^{n} \cdot n$ & 0.000 & 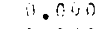 & 7.11119 & $.1 \div !$ & .508 & $\cdot 4+4$ & 1. A5E & \\
\hline $21 \cdot 7$ & 9.000 & $(1,0,0)$ & 0.000 & .075 & .542 & $.45)$ & 1.521 & \\
\hline $2>0$ & 3000 & $7.00 \mathrm{ij}$ & 0.010 & - nr: 1 & .450 & - $i 21$ & 1.452 & \\
\hline$? ? .0$ & 0.000 & 7.020 & 0.0 .110 & .054 & $.44 !$ & .40 .1 & $\therefore .156$ & \\
\hline$? \cdot \cdots$ & 0.500 & 0.0010 & 9.000 & .034 & .301 & $=214$ & 1.030 & \\
\hline 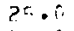 & 0.906 & $0.0 \cup 0$ & ?. nol & .022 & .353 & $-24+$ & $.47 ?$ & \\
\hline$\therefore \therefore$ & 19.00i & 0.040 & 0.0110 & - i) $2 ?$ & .205 & - Si: & .432 & \\
\hline$=7.3$ & orous & 0.000 & 0.000 & - 14! & $.25 \%$ & $\therefore \rightarrow 7$ & .143 & \\
\hline $\bar{c} \cdot n$ & 0.000 & r.inn & 0.000 & 0.000 & . 201 & . $\cdots$ & $.5,74$ & \\
\hline 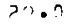 & $\therefore .300$ & 9.750 & .9 .10 & ans. & . 134 & $.6 ?$ & $.59 \pi$ & \\
\hline $3 r \cdot 0$ & 0.005 & 9.350 & ..1100 & 0.000 & .15 & 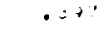 & $.36=$ & \\
\hline $5 ! \cdot 0$ & 0.000 & 0.000 & 7.000 & $0.0 \div \pi$ & .173 & . 3.4: & . & \\
\hline $3>0$ & 19.000 & 0.000 & $n .110$ & 0.000 & .155 & .374 & .475 & \\
\hline $7 \%$ & "). & $n .700$ & 0.0100 & 1). & +134 & ו כ ג , & .475 & \\
\hline 34.0 & if. 0 if? & 0.010 & 0.0110 & $\therefore 000$ & $.17: 4$ & - 21 & $.4: 9$ & \\
\hline $3 \because . ?$ & r.son & $n .700$ & 5.0 .20 & 0.000 & .100 & $.1 ?$ & $.3+3$ & \\
\hline 36.0 & n.tra & 0.000 & $n .0110$ & $0 \cdot i_{2} 0 \bar{u}$ & .084 & .154 & .513 & \\
\hline 37.7 & $r . \bar{n}$ & $0.9 ; 4$ & $n . \sin 0$ & [. 0 ก? & . $: 61$ & $.1 \% 2$ & . ris & \\
\hline$x \therefore 0$ & n.jous & 8.05 & 0.000 & (i. $2 n_{i 1}$ & $.0=u$ & . is & .274 & \\
\hline $2 \because n$ & $n .101$ & reris & $\{.\{: 9\}$ & $0.03:$ & {$\left[\begin{array}{c}03+1 \\
0\end{array}\right.$} & $.1 \div$ & .214 & \\
\hline
\end{tabular}

Figure 10. Cumulative Frequency Distribution of the Change in Direction, $\Delta \theta$, in time $\Delta t$ for the HUB (Case 1) 


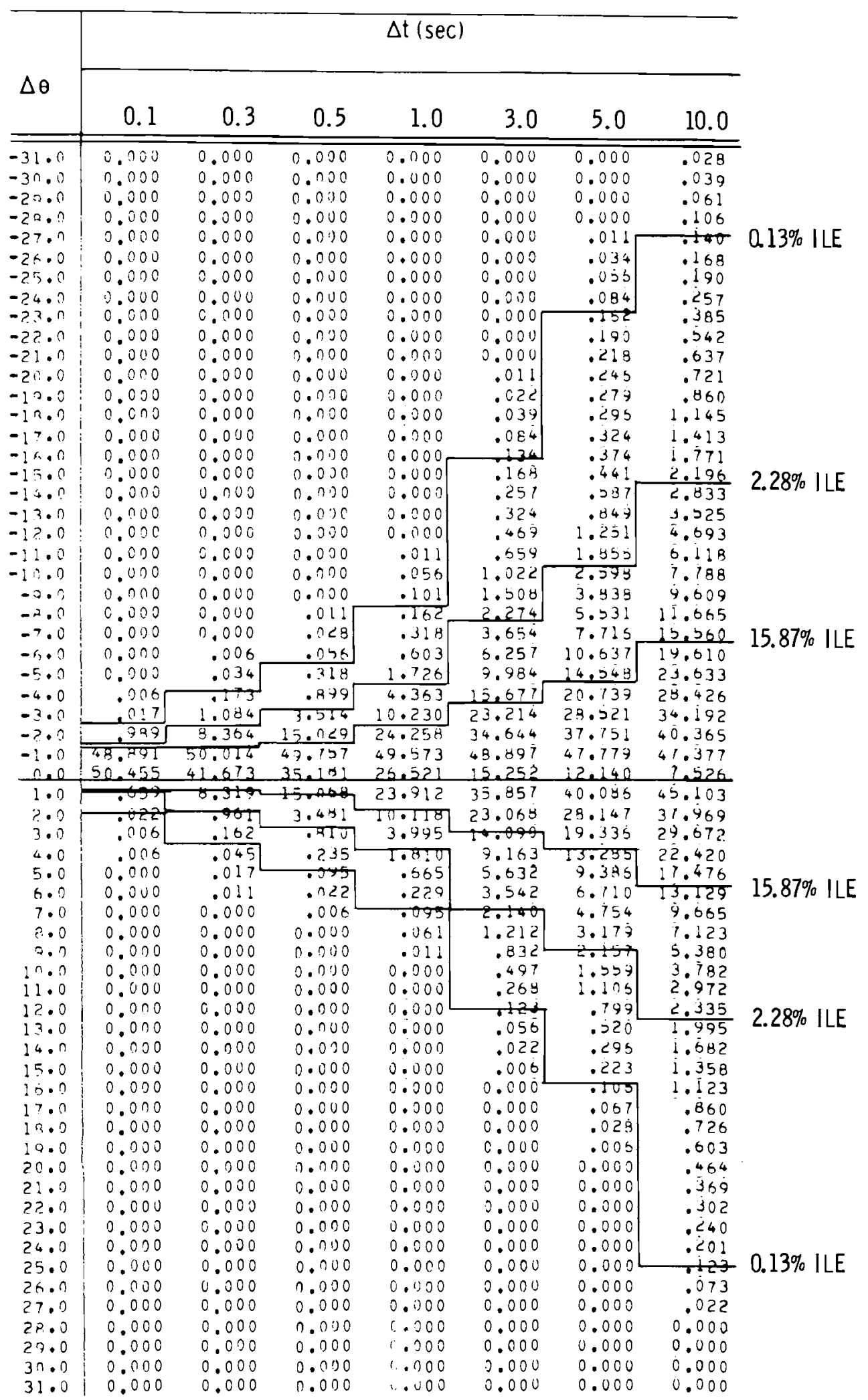

Figure 11. Cumulative Frequency Distribution of the Change in Direction, $\Delta \theta$, in time $\Delta t$ for the ARRAY AVERAGE (Case 2) 


\begin{tabular}{|c|c|c|c|c|c|c|c|c|}
\hline & & & & $\overline{\Delta t}(\sec )$ & & & & \\
\hline & 0.1 & 0.3 & 0.5 & 1.0 & 3.0 & 5.0 & 10.0 & \\
\hline $\begin{array}{l}-39.1 \\
-39 . n\end{array}$ & .145 & $\begin{array}{l}.034 \\
.061\end{array}$ & $\begin{array}{l}.11<2 \\
.039\end{array}$ & $\begin{array}{l}.039 \\
.067\end{array}$ & $\begin{array}{l}.084 \\
.095\end{array}$ & $\begin{array}{lll}1 & 1 & 2 \\
1 & 2 & 2\end{array}$ & $\begin{array}{l}.240 \\
.307\end{array}$ & \\
\hline-37.0 & .173 & .051 & .1145 & . OA9 & .112 & .164 & .346 & \\
\hline $\begin{array}{l}-36.0 \\
-35.0\end{array}$ & $\begin{array}{lll}-2 & 1 & 7 \\
.2 & 1 & 2\end{array}$ & $\begin{array}{l}.061 \\
.051\end{array}$ & $\begin{array}{l}070 \\
.096\end{array}$ & $\begin{array}{l}.035 \\
.112\end{array}$ & $\begin{array}{l}.151 \\
.154\end{array}$ & $\begin{array}{l}190 \\
.240\end{array}$ & $\begin{array}{r}.403 \\
.453\end{array}$ & \\
\hline-34.0 & .223 & .013 &.$n n !$ & .117 & .207 & .279 & .592 & \\
\hline $\begin{array}{l}-3.3 .0 \\
-32.0\end{array}$ & .263 & .049 & 01133 & .145 & .274 & . 35? & .732 & \\
\hline $\begin{array}{l}-32 \cdot 0 \\
-31 \cdot ?\end{array}$ & .346 & $\begin{array}{l}.112 \\
.1235\end{array}$ & 14 & $\begin{array}{l}.176 \\
.240\end{array}$ & $\begin{array}{r}.315 \\
.3859\end{array}$ & $\begin{array}{l}.419 \\
.475\end{array}$ & $\begin{array}{l}.838 \\
.461\end{array}$ & \\
\hline-30.0 & $.4112^{2}$ & .173 & .173 & - Lat & .412 & .534 & 1.095 & \\
\hline $\begin{array}{l}-59.0 \\
-59.0\end{array}$ & $\begin{array}{r}.436 \\
.525 \\
642\end{array}$ & $\begin{array}{r}.291 \\
.257 \\
335\end{array}$ & $\begin{array}{r}.18 \\
.245 \\
2115\end{array}$ & $\begin{array}{r}.15 a \\
.425 \\
.486\end{array}$ & $\begin{array}{l}.453 \\
.431 \\
626\end{array}$ & $\begin{array}{r}.637 \\
.715\end{array}$ & $\begin{array}{l}1.201 \\
1.352\end{array}$ & \\
\hline $\begin{array}{l}-27 \cdot ? \\
-24 \cdot n\end{array}$ & $\begin{array}{l}.04 C \\
.785\end{array}$ & $\begin{array}{l}.135 \\
.346\end{array}$ & $\begin{array}{l}.215 \\
.313\end{array}$ & $\begin{array}{l}.4 \mathrm{HB} \\
.59 ?\end{array}$ & $\begin{array}{l}.626 \\
.121\end{array}$ & $\begin{array}{r}.797 \\
.922\end{array}$ & $\begin{array}{l}1.503 \\
1.697\end{array}$ & \\
\hline-25.0 & .877 & .437 & .4119 & .059 & .416 & $\therefore .045$ & 1.905 & \\
\hline-24.0 & .994 & .531 & $.4 \times n$ & - vis & .461 & 1.207 & 2.134 & $2.28 \%$ ILE \\
\hline-23.0 & 1.1 .34 & .603 & .575 & .933 & 1.101 & 1.374 & 2.425 & \\
\hline $\begin{array}{l}-27 \cdot 0 \\
-21 \cdot 0\end{array}$ & $\begin{array}{l}1.253 \\
1.454\end{array}$ & $\begin{array}{l}.710 \\
.427\end{array}$ & $\begin{array}{l}.517 \\
.1327\end{array}$ & $\begin{array}{l}1.117 \\
1.3 ? 4\end{array}$ & $\begin{array}{l}1.264 \\
1.469\end{array}$ & $\begin{array}{l}1.570 \\
1.349\end{array}$ & $\begin{array}{l}2.816 \\
3.185\end{array}$ & \\
\hline$-20 \cdot 0$ & 1.749 & 1.030 & $.4 \times 7$ & lesh's & $\therefore 7813$ & $2.14 j$ & 3.004 & \\
\hline-19.0 & 2.040 & 1.291 & $1 \cdot 1 \cdot, 1$ & 1.44. & 2.109 & 2.430 & 4.105 & \\
\hline$-i \beta .0$ & ח & 1.531 & 1.441 & 2.2215 & 2.441 & ח & 4.099 & \\
\hline-17.1 & $7.7 \mathrm{A2}$ & 1.717 & 1.755 & $2 \cdot n .31$ & 2.043 & 3.503 & $5.49 \mathrm{~A}$ & \\
\hline-16.0 & 3.359 & 2.241 & $2.1 / 9$ & 3.164 & $3.40: 3$ & 4.173 & $5.40 \mathrm{~A}$ & \\
\hline$-15 \cdot 0$ & 4.000 & $2.13 ?$ & 2.6द5 & $3.0 \geq 1$ & 4.162 & 4.421 & 7.409 & \\
\hline$-14 \cdot n$ & .0794 & 3.257 & $3 \cdot 234$ & 4.632 & , 1) & 5.149 & 8. & \\
\hline-13.0 & 5.704 & 4.045 & 3.467 & $5.11+3$ & 6.134 & 7.125 & 9.034 & \\
\hline$-12 \cdot 7$ & 7.042 & 4.912 & $4 \cdot 4 \cdot 46$ & 1.117 & 1.191 & 4.453 & 11.481 & \\
\hline$-11 \cdot n$ & 8.459 & 6.017 & $6 \cdot 263$ & 6.572 & 3.017 & 10.090 & $10.4 \mathrm{nl}$ & \\
\hline$-i n .0$ & 10.151 & 7.503 & $0.11 / 3$ & 10.336 & $\therefore .1350$ & 12.057 & مهرهـ & $15.87 \%$ ILE \\
\hline$-9 . n$ & 12.369 & 0.531 & 3.1 .14 & 12.536 & $: 3.330$ & 14.364 & 15.264 & \\
\hline$-P \cdot]$ & 15.160 & 11.039 & 12.139 & كنه. 15 & r & 17.190 & 20.427 & \\
\hline-7.0 & 14.264 & 15,241 & {$[\overline{1}$} & 16.174 & 11.135 & 20.297 & 23.91 .5 & \\
\hline$-x \cdot n$ & 22.174 & 19.1 .311 & 10.212 & T1. 2 ints & 2.2 .13 .4 & 2.3 .519 & 21.289 & \\
\hline-5.0 & 20.530 & $>3.7 \mathrm{hl}$ & 23.95 & 25.110 & 20.960 & $2: 1.373$ & 31.102 & \\
\hline-4.0 & 31.627 & 29.937 & 29.1 .29 & 31.253 & 31.47 .3 & 32.45 & 37.404 & \\
\hline-3.0 & 37.125 & 35.595 & 35.4011 & 36.0179 & 37.572 & 37.929 & 34.566 & \\
\hline$-2 \cdot 0$ & 43.243 & 47.514 & $4 ? .136$ & 43.1125 & 4.3 .427 & 43.220 & 44.125 & \\
\hline-1.0 & 49.452 & $49.9 \cdot 5$ & 47.522 & 44.2179 & $4 \% A B$ & 49.0125 & $4 \bar{B} .447$ & \\
\hline 2,0 & 5.961 & $7.52:$ & 1.7 .5 & 2.1472 & $0.40: 3$ & 5.3394 & 4,080 & \\
\hline $1 \cdot 0$ & $43.19 ?$ & 42.500 & 47.729 & $4.3 .4 \times 4$ & 4.91 .3 & 45.016 & 46.170 & \\
\hline $2 \cdot n$ & 36.942 & .35 .530 & $35.7 s^{\prime}$ & 37.928 & 91.907 & 30.393 & $41.47 ?$ & \\
\hline 3.0 & $31: 365$ & 29.013 & 23.057 & 32.1153 & $32.24 i$ & 33.711 & 36.096 & \\
\hline $4 . n$ & 26.236 & 23.643 & 23.490 & 20.515 & 20.934 & 20.750 & 32.443 & \\
\hline 5.0 & 21.066 & 19.113 & 10.046 & 22.135 & 32.443 & 24.141 & 27.974 & \\
\hline 6.0 & 17.400 & 15.423 & T.3द5] & 17.979 & 13.666 & 20.051 & 24.37 .8 & \\
\hline $7 . n$ & الم & 12.769 & 10.112 & 7.5092 & $13.45: 2$ & 14.233 & 20.648 & \\
\hline in 0 & 17.254 & 9.721 & 9.712 & 11.499 & 12.000 & 13.816 & 17.616 & $15.87 \%$ \\
\hline 0.0 & 10.213 & 7.861 & $7 \cdot 4 / 6$ & 9.6119 & 30.626 & 11.397 & $15.00 \%$ & \\
\hline 19.0 & $8.5 \geq 0$ & $6.35 ?$ & 6.กบD & 7.716 & 8.777 & 9.369 & $12 . \ln 5$ & \\
\hline $11 \cdot 0$ & 7.045 & 5.0115 & 4.922 & 6.375 & 7.213 & 7.654 & 10.744 & \\
\hline $12 \cdot 0$ & 5.83 .3 & 4.045 & $3.0 n 7$ & 5.235 & $6.02 \mathrm{i}$ & $n .300$ & Y.us! & \\
\hline 13.0 & 4.877 & $3.3 B 11$ & 3.2117 & 4.206 & 5.020 & 5.436 & $1.645 j$ & \\
\hline $14 . n$ & 4.134 & 2.734 & $>.6 n t 7$ & $3: 5,3$ & 4.160 & 4.442 & 0.425 & \\
\hline 15.0 & 3.503 & 3.1311 & ?.154 & 2.920 & 3.391 & 3.699 & 3.425 & \\
\hline 16.0 & 2.961 & 1.771 & $1.73 n L$ & $2 .+44$ & 7.844 & 3.123 & 4.576 & \\
\hline 17.0 & 2.564 & 1.457 & 1.596 & ?.116? & 23164 & 2.635 & $3.87 \%$ & \\
\hline$i^{n} \cdot 0$ & t. & 1.211 & $1 \cdot 25 \%$ & $1.7>6$ & 2.017 & 7.102 & 3. $\angle A S$ & \\
\hline 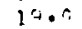 & 1.877 & .3543 & i. on & 1.441 & 1.771 & 1.750 & 2.734 & \\
\hline $2 \cdot n$ & 1.587 & $.7 n d$ & .2213 & $1.1 ; i$ & 1.43 & $1.430 L$ & 2,363 & $2.28 \%$ ILE \\
\hline $21 \cdot n$ & 1.303 & .631 & $.7 n s$ & $\because, c_{1} c_{1}$ & $1.80 i$ & 1.179 & $2.02 \%$ & \\
\hline $22 \cdot 11$ & $1.1 \mathrm{AH}$ & .531 & $.44 i^{2}$ & $.51 \% 4$ & $1.00 n$ & .994 & 1.743 & \\
\hline 23.7 & 1.073 & .447 & $.44 ?$ & $.76,5$ & .1144 & .832 & 1.531 & \\
\hline $24 \cdot ?$ & $.9 \times 1$ & .391 & $\infty \rightarrow C_{3}$ & 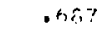 & .760 & .642 & 1.341 & \\
\hline $2=0$ & . Fas & .813 & 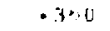 & -5ats & .031 & .592 & $i . j 45$ & \\
\hline $2^{4} \cdot 6$ & .732 & .274 & .313 & - So!: & $.34 ?$ & .508 & .955 & \\
\hline 27.5 & $63 !$ & .223 & .235 & .447 & .469 & .441 & .866 & \\
\hline $2^{2} \cdot 0$ & .570 & .146 & $\cdot 1: 14$ & .335 & .408 & .397 & .715 & \\
\hline 20.6 & .531 & $.15 \%$ &.$|4|$ & - 256 & .318 & .352 & .637 & \\
\hline $37 \cdot 0$ & .441 & $.14 \leqslant$ & Till & .223 & .268 & .367 & .553 & \\
\hline $3 ! \cdot 0$ & . 3Ri: & لهيخ:. & .018 & $.20 i$ & .212 & .257 & .480 & \\
\hline $32 \cdot 0$ & $35 \dot{c}$ & .117 & 1174 & $.1 \in 2$ & .184 & .212 & .436 & \\
\hline $33 \cdot r$ & .279 & .084 & .967 & .151 & $.15 \theta_{2}$ & .290 & .380 & \\
\hline 34.1 & .257 & ofitity & $\cdot n a, 1 L$ & T, & .117 & .162 & .330 & \\
\hline 35.1 & 2.2 .3 & .051 &.$! 44$ & .112 & .106 & .134 & - $31 \xi$ & \\
\hline $36 \cdot 6$ & $1: 6$ & . ris? & $-t_{1}+t$ & $061:<$ & $.18 i$ & .117 & .362 & \\
\hline 37.1 & 150 & .034 & .0 .45 & $.07 \%$ & .145 & | & .225 & \\
\hline 34.0 & .140 & . fiar & . 1) $3 i$ &.$n 5 c$ & .034 & $.1: 1$ & .173 & 0 \\
\hline $3 c \cdot r$ & .011 & .017 & - nci & - 145 & .028 & $.0 B \rightarrow L$ & 1.34 & \\
\hline
\end{tabular}

Figure 12. Cumulative Frequency Distribution of the Change in Direction, $\Delta \theta$, in time $\Delta t$ for a BLADE (Case 3) 


\begin{tabular}{|c|c|c|c|c|c|c|c|c|}
\hline \multirow{2}{*}{$\Delta \theta$} & \multicolumn{7}{|c|}{$\Delta \mathrm{t}(\mathrm{sec})$} & \\
\hline & 0.1 & 0.3 & 0.5 & 1.0 & 3.0 & 5.0 & 10.0 & \\
\hline$-2 \pi .0$ & anon? & 17110 & $\pi .0 .09$ & 0.000 & .0100 & .024 & .034 & \\
\hline$-33 \cdot n$ & n.5.10 & 0.0170 & ר. 0 ก & 0.000 & .011 & .1134 & .050 & \\
\hline$-3 \% 0$ & $\because n n^{\circ}$ & (1) n11) & 7.010 & 0.0 ino & .011 & .034 & .056 & \\
\hline$-3 ! \cdot 0$ & n. nni: & 1).010 & n. non & $0.0 \cap 0$ & .017 & .034 & .095 & \\
\hline$-3 r \cdot 0$ & acin? & 0.000 & 3.0100 & 0.000 & $.0 ! 7$ & .037 & 134 & U. $19 \%$ ILE \\
\hline-20.0 & 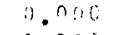 & $0.0 \times 1)$ & 0.190 & $0.0 \cap 0$ & .017 & .050 & $.18 ?$ & \\
\hline$-2 a \cdot 0$ & ת.0\%: & $n .011 i$ & $n .0 .10$ & 0.7 .00 & $.0 ? k$ & .055 & .229 & \\
\hline$>>0$ & $0 . \cap \cap 1)$ & 0.0010 & $0.70 n$ & 0.000 & .039 & .061 &.$<n 5$ & \\
\hline$P r .0$ & 0.000 & 11.000 & $? .0100$ & .011 & .050 & .057 & $.15 A$ & \\
\hline$->a . n$ & .017 & . ก15 & . nis & $.0>?$ & .050 & .089 & .453 & \\
\hline-2400 & .978 & .011 & . . & $.0>4$ & .043 & .105 & .525 & \\
\hline$-? 7.0$ & .921 & .011 & .914 & $.0,45$ & .067 & .51 & .070 & \\
\hline$-2>\cdot n$ &.$\left.r r_{i}\right)$ & . C<'! & .119 & .013 & .100 & .145 & $.7 A 2$ & \\
\hline$-? 1 \cdot 0$ & . $\therefore<!$ & .0 .5 &.$n ! k$ & . Inf & لم2.2. & .240 & .955 & \\
\hline$-7 n \cdot n$ & . r.? & .0157 & .078 & لهידיד & .179 & .335 & 1.184 & \\
\hline$-1 \% 0$ & . $\cdots n n_{4}$ & .0384 & . 101 & $.1>3$ & $.2: 2$ & 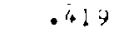 & 1.598 & \\
\hline$-1: n$ & $.12 u_{2}$ & .112 & 计 & $.8>3$ & .279 & .520 & 1.933 & $2.28 \%$ ILE \\
\hline$-17 \cdot 1$ & .164 & $.15 ?$ & .125 & $.3 ; 3$ & $.35 \theta$ & .7931 & 2.535 & \\
\hline$-1 \% \cdot n$ & $.2 \% ?$ & .2 .19 & .274 & .375 & $.50 \mathrm{H}$ & 1.095 & 2.177 & \\
\hline$-15 . r$ & . 313 & $.35 n$ & $.2 \operatorname{lng}$ & $.53:$ & .165 & 1.395 & 3.313 & \\
\hline$-14 \cdot 0$ & .630 & .536 & $\cdot 4 ! 4$ & .503 & 1.050 & 1.450 & 4.129 & \\
\hline$-1.3 \cdot 0$ & 年: 7 & .717 & .117 & $.9166_{0}$ & $1.4: 3$ & $64 ?$ & 4.472 & \\
\hline$-17 \cdot n$ & . 972 & $1 \cdot n_{10} f_{2}$ & 1.1113 & 1.300 & 2.011 & 3.229 & $6.21 \%$ & \\
\hline$-11 \cdot n$ & $1.35+4$ & $\therefore 4^{\prime \prime 14}$ & 1.454 & P.inn & 8.821 & 4.201 & 7.593 & \\
\hline$-1 \cdot n$ & $? .11 n$ & 2.055 & $\therefore .7175$ & 3.0713 & $\therefore .110$ & 5.592 & $\dot{9} . b 65$ & \\
\hline$-\therefore \cdot n$ & $7.2 ?^{2}$ & $3.05 \%$ & $7.21 ?$ & 4.396 & 5.6 .74 & 7.435 & 11.738 & \\
\hline$-x \cdot r$ & 4.777 & 4.397 & 6.437 & 6.179 & $n .257$ & 10.001 & 14.224 & $15.87 \%$ \\
\hline-7.0 & 7.070 & 6.635 & $-1,14 n$ & 3.961 & 111.567 & 12.978 & 7.693 & D. \\
\hline$-\cdots 0$ & $: 0.403$ & $0.54 ?$ & $10.4 \%$ & 12.573 & 14.6095 & لج110. & 21.253 & \\
\hline$-5 . n$ & 14.944 & $16.1 \% .11$ & 15,267 & T. & 19.535 & 21.773 & 25.300 & \\
\hline$-4 \cdot n$ & 72.161 & 211049 & $2 ! \cdot P^{n+1}$ & 23.532 & 25.792 & 27.421 & 30.001 & \\
\hline$-? \cdot n$ & 79.9 .24 & 79.426 & $2\{.947$ & $3: 080$ & 32.566 & 33.139 & 35.173 & \\
\hline-7.0 & 34.060 & 40.2710 & $37.04 r$ & 40.677 & $4: .097$ & 41.550 & 41.717 & \\
\hline$-1 \cdot n$ & 4.2 .309 & 51.721 & 6.9 .5 .93 & 50.405 & 51.159 & 49.735 & $4 \mathrm{H} .114$ & \\
\hline $0 . r$ & 1 Lent & Lr.e.191 & 11.200 & 0.420 & 0.101 & $8.0: 7$ & 0.665 & \\
\hline$i \cdot 2$ & 60.756 & 31.1124 & $4 ?_{1}, 213$ & 40.151 & $4 r .745$ & 42.254 & 45.226 & \\
\hline$>0$ & $=9.313$ & 20.025 & 27.401 & 31.107 & 37.650 & 34.533 & 36.298 & \\
\hline 3.0 & 20.54 .3 & 23.308 & 31.011 & 23.761 & 25.420 & 2.7 .577 & $31.72 A$ & \\
\hline $4 . n$ & 13.47 & $+2+3$ & $1+1,124$ & 17.442 & 19.437 & 21.415 & 25.549 & \\
\hline $5 . n$ & 9.370 & 16.520 & 0.431 & 12.3472 & -3.301 & $16.6 \cap 3$ & 20.359 & \\
\hline$n \cdot n$ & 6.123 & 7.259 & $\therefore .24 !$ & 4.692 & 10.408 & 12.364 & 16,124 & $15.87 \%$ ILE \\
\hline $7 \cdot ?$ & 4.284 & 4.727 & $4.7 \times 0$ & 0.176 & 7.553 & 9.230 & 12.015 & \\
\hline $2 . n$ & 2.350 & 3.235 & $? .02 ?$ & 4.302 & 5.531 & 6.771 & $9.87 ?$ & \\
\hline $0 \cdot n$ & ?.?? & $? .10 ?$ & T.ग10 & $2.97 ?$ & 3.782 & 4.972 & 7.72 .1 & \\
\hline $1 \cdots \cdot n$ & $1.39 \mathrm{H}$ & 1.41 .4 & 1.413 & 2.160 & $2.749:$ & $3.68 ?$ ? & 5.917 & \\
\hline 11.0 & .743 & .903 & .9104 & 1.458 & 7.000 & 2.5110 & 4.643 & \\
\hline $1=\cdot n$ & .743 & $.6: 3$ & .721 & 1.024 & 1.441 & 1.939 & 3.570 & \\
\hline 17.0 & $.5 \times 5$ & .436 & $.5 \sigma^{a}$ & $.7 .7 \%$ & 1.055 & 1.441 & 2.877 & \\
\hline 1400 & .14 & $.3 c 4$ & . & $.54 !$ & .737 & 1.129[ & 2.363 & $28 \% \mathrm{IL}$ \\
\hline$i=.0$ & . ? 19 & .218 & .740 & $.30 i$ & .587 & .894 & $\frac{1.911}{1.9}$ & \\
\hline 16.0 & $\therefore \angle 5$ & .151 & .173 & .274 & .447 & .704 & 1.603 & \\
\hline 17.0 & .1"n & .4 & $\rightarrow+4$ & .246 & .330 & .542 & i. .346 & \\
\hline $19 \cdot 0$ & .074 & .094 & .178 & .100 & .229 & .345. & 1.100 & \\
\hline 10.0 & $.0<1$ & . $\cap \in 7$ & - nक⿱ & وسند. & .151 & .295 & .877 & \\
\hline $2 r_{s} \cdot n$ & . i) 万is & .061 & $\therefore 94$ & .005 & 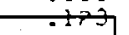 & .235 & .715 & \\
\hline$>1.0$ & .011 & . $(x)$ & . nis? & .07 .3 & .084 & .190 & $.62 A$ & \\
\hline $2 ? \cdot 0$ & $.0: 1$ & .039 & .1911 & .050 & $n \in 7$ & .156 & .581 & \\
\hline 3.3 .0 & orente & .030 & .016 & .039 & $.0 \leq 0^{\circ}$ & $\therefore$ & .469 & \\
\hline 24.0 & orf. & .011 & - rinn & - u>p & .1940 & .078 & .374 & \\
\hline 75.0 & . & .011 & eches & $.0>2$ & .039 & $.06 i$ & .285 & \\
\hline 26.0 & .006 & .011 & .016 & :n?? & .0 .39 & $.05 i$ & .229 & \\
\hline $2.7 \cdot 0$ & 0.000 & .011 & 0.000 & .011 & .039 & .034 & $.1 B_{4}$ & \\
\hline $2 h \cdot 0$ & 0.000 & .011 & 0.000 & $.00 \mathrm{~B}$ & $.03^{4}$ & $.0 \hat{E C}$ & .145 & $\%$ \\
\hline 20.0 & 0.000 & .006 & $0 . \cap+10$ & $.0 \cap A$ & .017 & .011 & 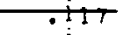 & . $13 \%$ TLL \\
\hline 30.0 & 0.0000 & 0.060 & 0.040 & 0.0011 & .017 & .0116 & . IOA & \\
\hline $31 \cdot 0$ & $0 . \sin \theta$ & 0.0100 & c.non & $c . n 00$ & .017 & .005 & .061 & \\
\hline 37.0 & 0.010 .0 & 0.0100 & n. nero & o.isc & .011 & .005 & .034 & \\
\hline 33.0 & 0.1100 & 0.000 & 0.000 & $0 . \dot{100}$ & .011 & $0.000 !$ & .034 & \\
\hline
\end{tabular}

Figure 13. Cumulative Frequency Distribution of the Change in Direction, $\Delta \theta$, in time $\Delta t$ for the BLADE AVERAGE (Case 4) 


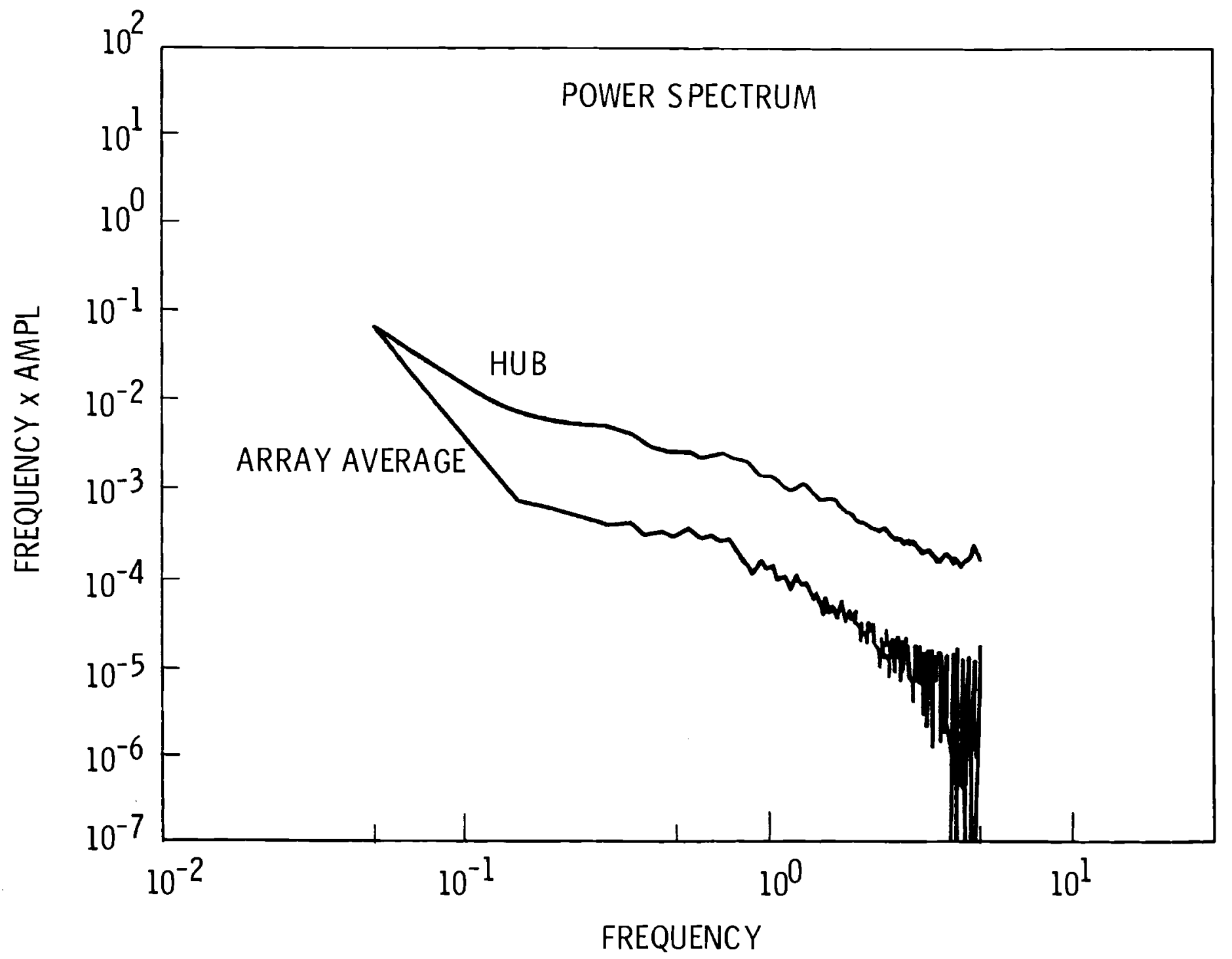

Figure 14. Power Spectra of Hub and Array Average 


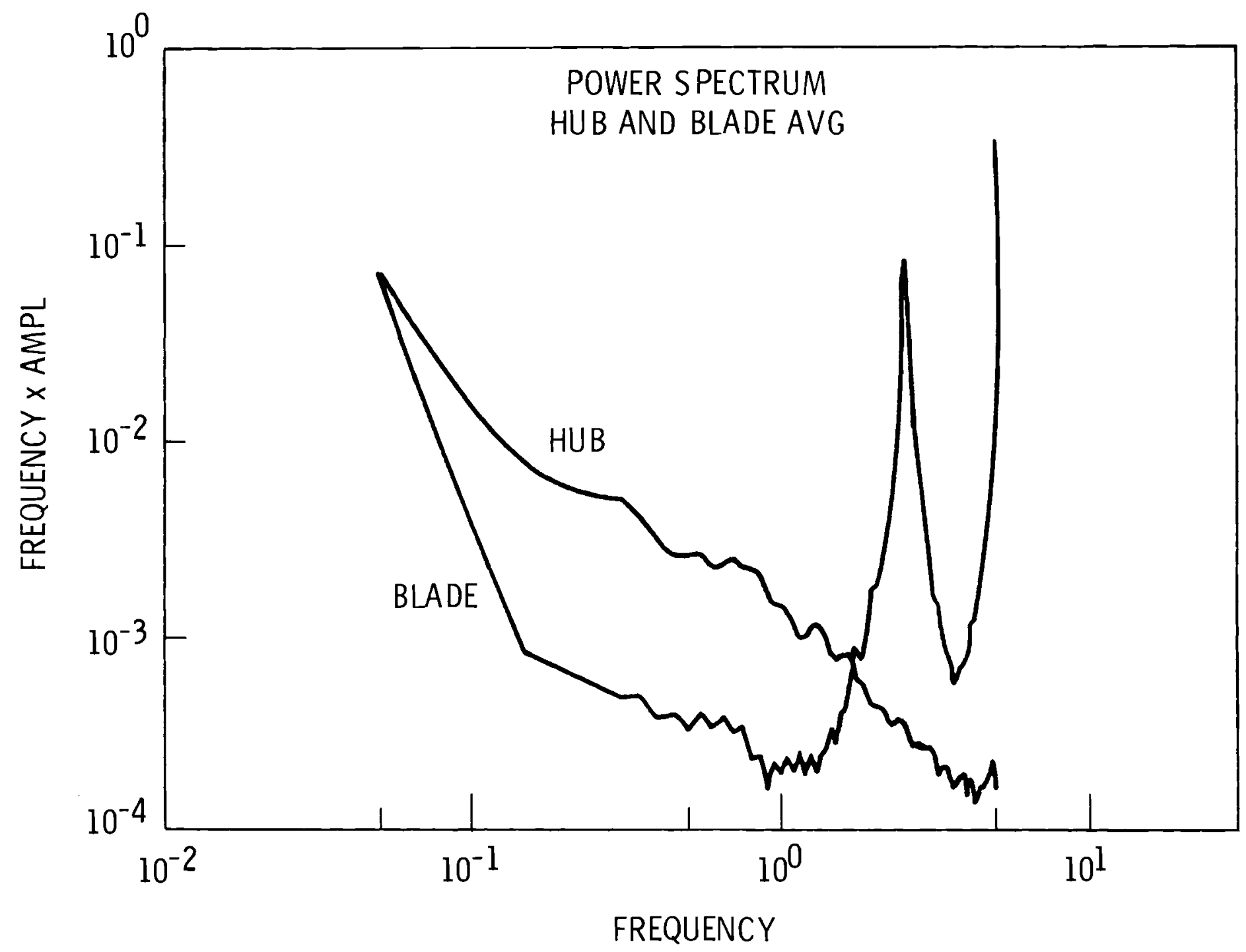

Figure 15. Power Spectra of Hub and Blade Average 


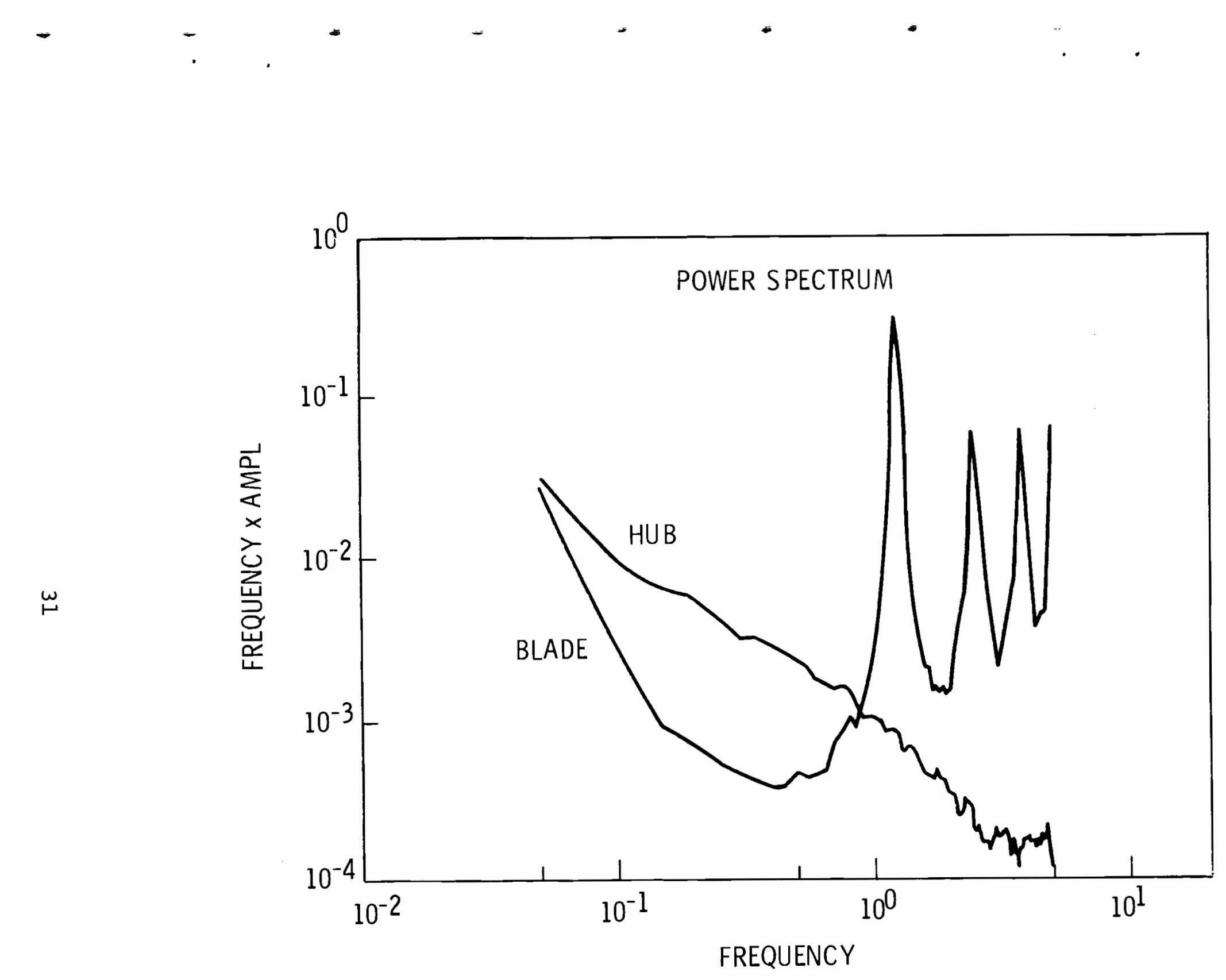

Figure 16. Power Spectra of $\mathrm{Hub}$ and Blade Tip 



\subsection{REFERENCES}

1. Cliff, W. C. and Verholek, M. G., "Flow Field Analysis," NASA CP-2034, Wind Turbine Structural Dynamics, NASA-LeRC, Cleveland, $O H 44135$, November 1977. 


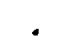




\section{PNL DISTRIBUTION}

No. of

Copies

OFFSITE

A. A. Churm

D0E Chicago Patent Group

9800 South Cass Avenue

Argonne, IL 60439

G. P. Tennyson

Department of Energy

600 E Street, N. W.

Washington, DC 20545

283 DOE Technical Information Center

Thomas Vonier

AWEA Windletter

2222 Q Street, N. W.

Washington, DC 20008

Dr. Paul B. MacCready, Jr.

Aerovironment, Inc.

145 Vista Avenue

Pasadena, CA 91107

Clarissa Quinlan

Alaska State Energy Office

338 Denali Street

Anchorage, AK 99501

Paut N. Vosburgh

Alcoa Allied Products

Aluminum Company of America

Alcoa Center, PA 15069

Dr. K. C. Spengler

American Meteorological Society

45 Beacon Street

Boston, MA 02108

Ben Wolff

American Wind Energy Association

$1717 \mathrm{~K}$ Street NW

Suite 1111

Washington, DC 20036
No. of

Copies

Richard Katzenberg

American Wind Energy Association

Natural Power, Inc.

New Boston, NH 03070

E. J. Warchol

Bonneville Power Administration

P. 0. Box 3621

Portland, OR 97208

S. J. Hightower

Bureau of Reclamation

Denver Federal Center

B1dg. 67, Code 254

Denver, C0 80225

M. Ginosar

California Solar Energy Commission

Energy Resources, Conservation and Development Commission

1111 Howe Avenue, Mai1 Stop 15

Sacramento, CA 95825

Robert Ball

Center for the Environment and Man, Inc.

275 Windsor Street

Hartford, CT 06120

Dr. R. J. Hawks

Clarkson College

Potsdam, NY 13676

Dr. R. N. Meroney

Colorado State University

Fort Collins, CO 80523

E. H. Gilmore

Department of Agriculture

Agriculture Research Service

Bushland, TX 79012 
No. of

Copies

L. A. Li1jedah1

Department of Agriculture Agriculture Wind Energy Program Building 001 , Room 126 BARC-West Beltsville, MD 20705

Douglas G. Fox

Department of Agriculture

Forest and Mountain Meteorology

Rocky Mounta in Forest and Range

Experiment Station

240 West Prospect Street

Fort Collins, CO 80521

Major T. E. Kullgren

DFCEM

USAF Academy, CO 80840

Jay Tappan

Department of Energy

State of Oregon

Labor and Industries Building

Room 111

Salem, OR 97310

Harry Moses

Department of Energy

Division of Biomedical and

Environmental Research

Mai1 Stop E-201

Washington, DC 20545

Carl Miner TAN-604

EG\&G Idaho, Inc.

P. 0. Box 1625

Idaho Falls, ID 83401

Dr. Edgar Demeo

Electric Power Research Institute

3412 Hillview Avenue

Palo Alto, CA 94303

Jim Lerner

Energy Resources Conservation and Development Commission

California Solar Energy Office

Mail Stop 15

Sacramento, CA 95825
No. of

Copies

Dr. 011 e Ljungstrom

FFA, The Aeronautical Research Institute

Forskningsstationen i Stockholm Drottning Kristinas Vag 47

S-114 28 Stockholm, Sweden

R. G. Lawford

Fisheries and Environment

25 St. Clair Ave. East

Toronto, Canada M4T 1 M2

Dr. W. Frost

FWG Associates, Inc.

R. R. 3, Box 331

Tullahoma, TN 37388

L. Krawitz

General Electric Company

P. 0. Box 8555

Philadelphia, PA 19101

R. C. Koch

Geomet, Inc.

15 Firstfield Road

Gaithersburg, MD 20760

C. G. Justus

Georgia Institute of Technology

Atlanta, GA 30332

Darryl Tompkins

JBF Scientific Corporation

1925 North Lynn Street

Suite 308

Arlington, VA 22209

Dr. J. B. Knox

Lawrence Livermore Laboratory

University of California

P. 0. Box 808

Livermore, CA 94550

Ms. Abbey Page

Maine Office of Energy Resources

55 Capitol

Augusta, ME 04330 
No. of

Copies

S. M. Howard

Meteorology Research, Inc.

P. 0. Box 637

Altadena, CA 91001

V. F. Garrett

Montana Energy and MHD Res. and

Dev. Inst., Inc.

P. 0. Box 3809

Butte, MT 59701

J. Konigsberg

Montana Energy Office

Capital Station

Helena, MT 59601

Phillip French

NASA Scientific and Technical Information Facility

P. 0. Box 8757

Baltimore/Washington International

Airport

MD 21240

R. A. Wolf

NASA/Lewis Research Center

Mail Stop 500-201

Cleveland, $\mathrm{OH} 44135$

M. J. Changery

National Oceanic and Atmospheric

Administration

National Climatic Center

Federal Building

Asheville, NC 28801

R. J. Templin

National Research Council of Canada National Aeronautical Establishment

M-2 Montreal Road

Ottawa, Ontario KIA OR 6

Ms. Peggy McDonald

N. E. Solar Energy Center

70 Memorial Drive

Cambridge, MA 02142
No. of

Copies

M. W. Edelstein

North American Weather Consultants

600 Norman Firestone Road

Goleta, CA 93017

R. B. Corotis

Civil Engineering - Tech.

Northwestern University

Evanston, IL 60201

E. W. Hewson

Oregon State University

Corvalitis, OR 97331

R. de Violini

Pacific Missile Test Center

CODE 3250-3

Point Mugu, CA 93042

S. C. Crow

Poseidon Research

11777 San Vicente Boulevard

Suite 641

Los Angeles, CA 90049

Dr. F. M. Vukovich

Research Triangle Institute

P. 0. Box 12194

Research Triangle Park, NC 27709

Terry J. Healy

Rockwe11 International

Rocky Flats Plant

P. 0. Box 464

Golden, C0 80401

R. E. Akins/J. W. Reed

Sandia Laboratories

Division 5443

P. 0. Box 5800

Albuquerque, NM 87115

R. M. Traci

Science Applications, Inc.

P. 0. Box 2351

La Jolla, CA 92038 
No. of

Copies

D. M. Hardy

Solar Energy Research Institute

1536 Cole Boulevard

Golden, CO 80401

Dr. C. M. Bhumralkar

Stanford Research

Institute, International

Menlo Park, CA 94025

C. Jump

US Army Corps of Engineers

Seattle District

P. 0. Box C3755

Seattle, WA 98124

Dr. T. Wentink, Jr.

University of Alaska

Fairbanks, AK 99701

Dr. P. Yuen

University of Hawaij at Manoa

Holmes Hall 240

2540 Dole Street

Honolulu, HI 96822

B. H. Bailey

State University of New York

1400 Washington Avenue.

Albany, NY 12222

C. E. Duchon

University of $0 k 1$ ahoma

200 Felgar Street

Norman, OK 73069

Dr. N. K. Wagner

Dept. of Civil Engineering

University of Texas

Austin, TX 78712

Dr. M. Garstang

University of Virginia

Charlottesville, VA 22903

Dr. R. W. Marrs

University of Wyoming

Laramie, WY 82071
No. of

Copies

R. K. Woodruff

Washington Public Power Supply System

P. 0. Box 968

Richland, WA 99352

David Kapus

Washington State Division of

Engineering and Architecture

106 Maple Park Drive

01 ympia, WA 98504

Ms. Susan Hosch

Washington State Energy Office

$400 \mathrm{E}$. Union Avenue, 1st Floor

Olympia, WA 98504

S. R. Epur

Wichita State University

P. 0 . Box 44

Wichita, KS 67208

ONSITE

2 DOE Richland Operations Office

G. L. Liffick

H. E. Ransom

54 Battelle-Northwest
W. C. Cliff
R. L. Conley
J. C. Doran
R. L. Drake
C. E. Elderkin (26)
R. K. Hadlock
M. M. Orgill
W. T. Pennell
E. H. Phinney
J. V. Ramsde 11
D. S. Renne
C. L. Simpson
M. G. Verholek (10)
L. L. Wende 11
Technical Information (5)
Technical Publications 